\title{
Fiscal policy coordination in a monetary union at the zero lower bound
}

\author{
Jocelyn Boussard * and Benoît Campagne *
}

\begin{abstract}
Following the 2008 Financial Crisis, Euro Area governments faced adverse economic environments: high ratios of public debt to GDP, depressed outputs and the prospect of monetary policy hitting the zero lower bound (ZLB). This article assesses to what extent the conduct of fiscal policy differs within a monetary union at the ZLB. Using a fiscal DSGE model with two regions (North and South) calibrated to replicate the conditions where, absent any additional shock, the Euro Area economy would have been stuck at the ZLB for three years starting in 2013, we show that cross-border spillovers from fiscal policy are substantially higher without monetary offset and increase with the extent of fiscal consolidation measures. Spillovers can amount up to half (resp. one sixth) of the domestic impact in the case of VAT-based (resp. spending-based) consolidations. Outside the ZLB, fiscal expansion in one region triggers monetary tightening which has negative effect in the whole union, and gives rise to gains from fiscal cooperation. At the ZLB however, national objectives tend to be closer and the coordinated policy is less consolidating. Moreover, cooperation encourages symmetric rather than asymmetric policies.
\end{abstract}

JEL Classification: E10, E61, E62, F45

Keywords: DSGE model, monetary union, ZLB, fiscal policy, coordination

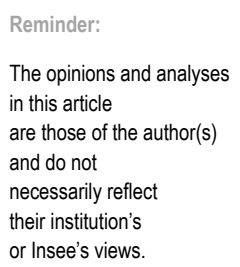

* Insee and Crest (jocelyn.boussard@insee.fr; benoit.campagne@m4x.org)

Acknowledgements - The authors thank Annabelle Mourougane for her fruitful discussion and advice on the first version of this paper, as well as all participants to the Insee research seminar. They also thank two anonymous referees for their constructive comments and suggestions. This research was conducted under Insee funding. 
$\mathbf{F}$ ollowing the large increases in public debts across the Euro Area after the 2008 financial crisis, the will to return to lower levels arose, either to reduce actual or perceived default risks that would drive the cost of public debts up, or to enhance future resilience and prepare for potential future shocks. However, fiscal consolidation tends to reduce economic activity in the short term, therefore creating a trade-off for governments between their willingness to reduce public debt levels and to foster the economy in the short term. Moreover, fiscal policy in one country of the Euro Area may affect the other countries, either positively or negatively, notably because of monetary policy reaction. The goal of this paper is to analyze how these spillovers are affected by the prospect of monetary policy becoming unresponsive to fiscal shocks (i.e. possibility of a Zero Lower Bound - ZLB hereafter - on interest rates). We use the Mélèze model developed at Insee (Campagne \& Poissonnier, 2016a), a state-of-the-art Dynamic Stochastic General Equilibrium (DSGE) model with imperfect financial markets where only one asset is tradable, in a monetary union calibrated to distinguish two regions: a North region including Belgium, France, Germany and the Netherlands, and a South region including Greece, Ireland, Italy, Portugal and Spain. These two regions were characterized by different inflation, productivity and hence competitiveness paths in the decade preceding the crisis, and reached different levels of debt and output, which may lead to different incentives for fiscal policy. We consider two illustrative fiscal policy instruments, public spending and value-added tax, and only temporary shocks.

Our first contribution is methodological. In order to take into account the existence of two monetary policy regimes (constrained and unconstrained), we endogenize the possibility to reach or exit the ZLB and solve the model in a piecewise linear fashion following Guerrieri and Iacoviello (2015). In contrast with most previous analysis, we replicate the initial conditions faced by Euro Area governments when the monetary policy reached the ZLB at the end of 2012. We back out structural shocks that replicate observed dynamics in the two regions from 2004 to 2015, simulate the baseline dynamics of the economy with these shocks and define fiscal policy as a deviation from this baseline scenario, taking the form of a temporary spending or VAT shock expected to last three years from 2013Q1 to $2015 \mathrm{Q} 4$. Then we simulate paths along a grid of different shock sizes, with ex ante deficit reduction ranging from $-5 \%$ to $+5 \%$ of steady state GDP. We then define a policy objective function for each region assuming the goal of governance is to increase the output and reduce the deficit, with decreasing marginal gains. We calibrate this policy objective such that inaction is the optimal policy at the steady state. We take a close look at the coordinated fiscal optimum at the ZLB and compare it to the uncoordinated Nash equilibrium. We also define the sustainability of the coordinated fiscal optimum as follows: a coordinated optimum is deemed sustainable when both regions are better off than at the Nash equilibrium. Because its implementation crucially depends on the willingness of governments to cooperate, we explore under which conditions the coordinated optimum is sustainable.

Our second contribution is positive and shows that in a monetary union, spillover effects from fiscal policy are substantially higher at the margin when monetary policy is constrained by the ZLB than when it is not: while the literature usually finds effects on foreign output that amount to $5 \%$ to $10 \%$ of the domestic effect outside the $\mathrm{ZLB}$, we find that those can reach $15 \%$ for spending-based consolidations, and $50 \%$ for VAT-based consolidations, when the monetary policy is constrained. Spillovers effects on economic activity of consolidation packages are also larger than those of stimulus packages, since a stimulus package will decrease the duration at the ZLB. The larger spillovers arising from VAT-based consolidations in case of ZLB reflect the fact that VAT hikes are less deflationary than public spending cuts, and have a stronger effect on the consolidating region's import demand.

Our third contribution is normative. We show, under the assumption that policy objectives are to increase activity and primary balance with decreasing returns, that the optimal coordinated policy is more expansionary at the zero-lower-bound, because fiscal multipliers are higher. We also show that larger spillovers mean that regional and union-wide objectives are closer and thus, coordination by external fiscal rules (such as the Stability and Growth Pact) is less necessary. Finally, in case of ZLB, we show that absent any default risk or financial constraint, that is if the central bank effectively acts as a lender of last resort, the optimal policy is somewhat similar in both regions. Indeed, because of large spillovers, stimulus in one region benefits it more than the other one, and thus, when both regions are depressed, decreasing gains from activity and primary balance imply that both regions should act in a similar way. 
As a result, for our calibrated policy objectives, the optimal coordinated spending policy when monetary policy hit the zero lower bound in 2012 would have been to increase public spending by $0.3 \%$ of GDP in the North and to decrease it by ex-ante $0.3 \%$ of GDP in the South, which is close to the uncoordinated policy of increasing spending by ex-ante $1.3 \%$ of GDP in the North and by $0.3 \%$ in the South. Outside the ZLB, if monetary policy was not constrained, the optimal coordinated spending policy would result in strong consolidations with decreased spending of $2 \%$ of GDP both regions, which is very different from the uncoordinated policy of increasing spending by $0.8 \%$ of GDP in the North and no additional action in the South. Similar results are found for VAT-based policies. We find that in all cases, while not technically stable, the cooperative equilibrium is sustainable.

\section{Literature}

Our research question is part of a large body of literature on fiscal reforms, inter-regional spillovers and policy coordination. The effects of fiscal policies have been studied along three main lines: (i) sizes of fiscal multipliers, (ii) trade-offs between short-term and long-term benefits of fiscal policy, and (iii) externalities in a monetary union.

Regarding the first two axes, the effects of fiscal policies have been shown to be strongly dependent on the context (position in the business cycle, monetary policy stance, etc.), and on their content (productive/unproductive expenditures, tax composition, etc.). In a standard New Keynesian framework with independent monetary policy, the fiscal multiplier is typically lower than 1 (Coenen et al., 2012). Coenen et al. (2008), in a two-region DSGE model of the Euro Area and the United States, show that the effect on production of fiscal consolidation (defined as a decrease in the target value of public debt) is negative in the short run, regardless of its composition, while it can be positive or negative in the long run, depending on its composition and the variable of interest. Similarly, using a world economy model with six regions and two types of households -liquidity-constrained and overlapping generations households- Clinton et al. (2011) show that short-term pain can be mitigated if the consolidation is permanent and leads to a long-term reduction in distortionary taxes with respect to the baseline case. In a monetary union, Roeger and in't Veld (2010) also show that permanent consolidations lead to lower short-term costs, because the decrease in debt service costs in the long run has a strong positive effect on current expectations.

However, for strongly integrated economies, and beyond the domestic scope of fiscal policy, there may be sizable spillover effects on trading partners. Indeed, in a monetary union, fiscal policy not only affects the demand that is addressed to other union members and the real effective exchange rate, but also the union-wide interest rate (Farhi \& Werning, 2016). Similarly, Erceg and Lindé (2013) study how currency union membership modifies the optimal composition of a fiscal consolidation package. They show that, at the domestic level, a tax-based fiscal consolidation may be preferable in the short run to a spending-based fiscal consolidation (defined as in Coenen et al., 2008), in contrast with the standard case of an open economy with independent monetary policy. This stems from the fact that cuts in public spending are more deflationary, and while independent monetary policy will mitigate their effects, a more distant central bank will react less, which increases their effect on output. They also find that the size of spillovers on foreign activity varies from $1 / 5$ th to $1 / 10$ th of the domestic impact on activity. This scale of spillovers is in line with in't Veld (2013) or Cwik and Wieland (2011), who also find external spillovers of $1 / 10$ th to $1 / 20$ th of the domestic impact for transitory consolidation programs in one Euro Area member on its trading partners, and corroborates our results outside the ZLB.

In addition, in't Veld (2013) shows that during a crisis, if the share of liquidity-constrained households is high and monetary policy is at the ZLB, spillover effects can be even larger: a Euro Area-wide fiscal consolidation nearly doubles the negative effect on any given region, compared to the case where that region is the only one consolidating. Conversely, Cwik and Wieland (2011) argue that the positive effect of the German stimulus plan on other Euro Area economies was offset by the negative effect of a real effective exchange rate appreciation vis-a-vis the rest of the world. Note that, as mentioned above, the stance of monetary policy, in particular if it is constrained by the zero-lower-bound, affects the fiscal multiplier (Christiano et al., 2011). More generally, and beyond the scope of the present paper, the conduct of fiscal policy (coordinated or uncoordinated) should take the whole economic environment into account. 
Indeed, Annicchiarico et al. (2013) show for instance, in the specific case of Italy, that fiscal consolidation substantially reduced the benefits of business-friendly reforms after the financial crisis, in part because of the lack of independent monetary policy response to offset the effects of fiscal consolidation. Likewise, Furceri and Mourougane (2010) show that when taking into account the feedback effect of risk premium on government bonds in a monetary union without lender of last resort, short-term effects of stimulus packages are still positive, even more so for spending-based or wage tax-based policies.

All in all, these papers clearly posit the existence of spillovers in a monetary union. As such, those spillovers need to be taken into account when designing consolidation or stimulus programs. Our paper directly follows this literature and takes a broader normative approach to assess whether fiscal policies could have been better coordinated post crisis within the euro area.

\section{Model}

We use the Mélèze DSGE model, developed by Campagne and Poissonnier (2016a) on the basis of two standard models of the Euro Area (Smets \& Wouters, 2003; Christiano et al., 2005). Designed to be as parsimonious as possible, ${ }^{1}$ this model consists of two aggregate regions in a monetary union trading partially substitutable goods. In each region, firms and households interact on the goods, labor and capital markets. Both firms and households, as well as production factors are considered immobile across regions, but cross-border financial flows are allowed in the union and with a Rest-of-the-World.

Firms produce partially substitutable goods with a standard constant return to scale production function. Given our short-term - cyclical rather than structural- focus, total factor productivity (TFP) is exogenous and growing at the same pace in both regions. Price and wage stickiness "à-la-Calvo" (Calvo, 1983) allows for monetary policy to play a role in our model. To keep the labor market framework simple, there is no unemployment and labor only adjusts at the intensive margin.

In addition, following Gali et al. (2007), households are distinguished between "Ricardian" and "non-Ricardian". This distinction enables to replicate credible private consumption behaviors following fiscal policy shocks. Therefore, a fraction of households, Ricardian households, are financially unconstrained, hold financial assets (or debt) and own capital which they lend to firms in their region, whereas non-Ricardian households consume their full current income, and consequently do not hold any asset.

In each region, the government behaves according to a standard budget rule where public consumption ensures the convergence of the public debt to GDP ratio towards its steady state level. Moreover, it collects taxes on wages, consumption and investment, provides lump-sum transfers and borrows on financial markets. Public debt is traded across borders, and we assume that because of incomplete financial markets public debt is the only tradable asset.

The central bank sets the nominal interest rate common to both regions through a Taylor rule (Taylor, 1993), where it reacts to current consumer price inflation. ${ }^{2}$ In simulations where we allow for the existence of a ZLB, the effective nominal rate on households' wealth cannot fall below a particular level, slightly above zero, to account for liquidity spreads. Financial frictions, in particular debt default and associated feedbacks on the yield curve, are voluntarily left out of the model, where we focus on the case where the central banks effectively act as a lender of last resort. However, to ensure the convergence of our open economy model, financial spreads proportional to the set of managed financial assets are introduced as in Schmitt-Grohe and Uribe (2003). Those spreads are calibrated to have a negligible impact on the model dynamic. The Rest-of-the-World, with which the currency union trades only in the form of assets, also obeys a budget rule to ensure convergence in the long-run.

Lastly, structural and policy shocks are introduced. Specific to each region, structural shocks hit preferences, productivity, labor supply and investment costs. Also, specific to each region, policy shocks hit public spending, public transfers, cost of public debt and net foreign assets. The union-wide policy shock is a monetary policy shock. In the estimating step of the model,

1. A specific focus on fiscal authorities is made below and a detailed outline of the complete model is provided in the Online Complement C1. Further robustness tests of both the calibration and the behavior of the model are presented in Campagne \& Poissonnier (2016a) and Campagne \& Poissonnier (2016b)

2. Including the output gap into the Taylor rule should reinforce our results as it will result in a stronger convergence of regional objectives at the ZLB (see below). In addition, absent official estimations of the Taylor rule, we choose to implement a rule consistent with the official mandate of inflation targeting. 
measurement errors on public assets and inflation are introduced.

\section{Fiscal Authorities}

Tax rates on consumption and labor are deterministic and arbitrarily chosen by the government. This choice is consistent with a low variability of apparent tax rates in the data over the calibration period. In the absence of public production or employment in the present model, all dimensions of public expenditures are encompassed through public consumption, which endogenously reacts to economic developments. A noteworthy assumption is that public consumption is fully domestic. In addition, public investment (defined as public expenditures increasing public capital stock) is not considered as an instrument of fiscal policy in the model. We discuss the impact of this simplification in further details in section $\mathrm{V}$.

Lastly, government behavior is modeled through a budget rule inspired on Corsetti et al. (2010). This rule is such that each regional government follows a convergence criterion derived from the Stability and Growth Pact. It adjusts its public expenditures in order to achieve convergence of its debt to GDP ratio to its target -here the pre-crisis (steady state) debt level to GDP- at an average yearly rate of convergence $\rho_{\mathrm{g}}$ of $1 / 20$ th of the previous period's deviation from the target ratio.

$G_{t}^{i}-\bar{G}^{i}=\rho_{g}\left(p a_{t-1}^{i}-\overline{p a}^{i}\right)$

where $G_{t}^{i}$ denotes the level of public expenditures in region $i$ and $p a_{t}^{i}=P A_{t}^{i} / P_{t}^{i} \bar{Y}^{i}$ the public debt to GDP ratio. $\bar{G}$ and $\overline{p a}$ denotes the steady state level of each variable.

All in all, the government is budget constrained by:

$$
\begin{aligned}
P A_{t}^{i} & =\left(R_{t-1}-\psi^{g}\left(\frac{P A_{t-1}^{i}}{P_{t-1}^{i} \bar{Y}^{i}}\right)\right) P A_{t-1}^{i} \\
& +v_{t}^{c, i} C P I_{t}^{i}\left(C_{t}^{i}+I_{t}^{i}\right)+v_{t}^{w, i} W_{t}^{i} L_{t}^{i}-P_{t}^{i} G_{t}^{i}-\Phi_{t}^{i}
\end{aligned}
$$

where $P A_{t}^{i}$ denotes the nominal public assets of region $i$ at the end of period $t$. The budget balance includes proceeds from value-added tax $\left(v^{c}\right)$ levied on private consumption and investment valued at consumer prices $C P I_{t}^{i}\left(C_{t}^{i}+I_{t}^{i}\right)$, and from labor tax $\left(v^{w}\right)$ levied on the wage bill $W_{t}^{i} L_{t}^{i}$. Public consumption is denoted $G_{t}$, and $\Phi_{t}^{i}$ nominal transfers to households. In addition, $R_{t}$ denotes the gross nominal interest paid on financial assets reduced/ augmented by negligible transaction spreads

$\psi^{g}\left(\frac{P A_{t-1}^{i}}{P_{t-1}^{i} \bar{Y}^{i}}\right)$.

\section{Calibration}

\section{Structural and non-structural parameters}

The model is calibrated to distinguish two regions within the Euro Area and match their pre-crisis situation: a North region including Belgium, Germany, France and the Netherlands, facing a South region comprising Ireland, Greece, Spain, Italy and Portugal. Northern countries are those with lower inflation and thus higher competitiveness gains before the crisis, while the cut-off point was decided as to make the two regions of similar size (in terms of population). This criterion follows a core-periphery approach and reflects the idea that observed differences in pre-crisis competitiveness might partially explain the differences in post-crisis responses with larger increase in public debts in countries such as Italy and Spain compared to Germany and the Netherlands.

The calibration is constructed to stay close to the traditional DSGE literature and to Eurostat's National Accounting data following a methodology similar to Campagne and Poissonnier (2016a). ${ }^{3}$ It follows a two-step approach. First, "deep" structural parameters are calibrated based on an extensive literature review, and median values are selected within the range identified in the literature. As far as possible, region-specific data are used to construct adequate aggregate parameter values for each region. Unfortunately, the lack of cross-region analyses crucially limits our ability to tailor region-specific calibrations, and a large number of parameters were calibrated according to values identified in the EU empirical literature. Moreover, even region-specific parameters tend to have identical values, after aggregation of country-specific figures within each region (for instance, the degree of substitutability between goods). In a second step, remaining parameters are estimated by first order moment matching of observed data for a large number of endogenous variables (reverse inference) and subjected

3. The methodology is presented in more details in the Appendix 1. 
to the steady state constraints. ${ }^{4}$ Tables 1 and 2 present the values for the structural parameters and the main endogenous steady state variables. Parameters for inflation, TFP growth and technology are imposed to be equal across regions even if data suggests otherwise. As explained in Campagne and Poissonnier (2016a), these restrictions are necessary for the mathematical existence of a steady state solution. ${ }^{5}$

As for the fiscal policy block, the government follows a budget rule and hence targets a public debt to GDP ratio calibrated on National Accounting data. ${ }^{6}$ We follow a calibration process similar to Coenen et al. (2008) for the calibration of NAWM (New Area-Wide Model of the Euro Area). Tax rates are calibrated using the implicit tax rates by economic function computed by Eurostat. Transfers $\left(\Phi^{i}\right)$ are used to clear the government budget constraints in the reverse inference process allowing to target the share of public consumption in GDP.

We also assume that public bonds are considered safe by all agents. This assumption seems reasonable to us since as we simulate the effect of fiscal policy starting in 2013, and we argue that from December $2012^{7}$ the European Central Bank was perceived to act as a lender of last resort, and the importance of default risks' mechanisms for the conduct of fiscal policy was mitigated.

Note that in the long run our model represents a closed monetary union and the choice of a public debt to GDP target implies that the sum of public debts of governments are equal to that of the private assets of households. Whereas the net foreign asset position of the North region vis-a-vis the Rest-of-the-World (including the rest of the Euro Area) is only $1 \%$ of GDP in 2007 , and can therefore be neglected, the South net foreign debt of $53 \%$ of GDP. In the model, this large net external debt is arbitrarily attributed within our regions, and the private assets to GDP ratios will not reflect actual data. In practice, the first order moment matching process suggests a solution where most of this external debt is assumed to be owed by South households.

\section{Baseline shocks}

The Euro Area reached the ZLB at the end of 2012, when the Euribor rate fell below 25 basis points. We argue that fiscal shocks starting in 2013 may have had different effects on regional outputs, that in turn affected the optimal behavior of regional governments.

Using Eurostat quarterly data on consumption, investment, output, public debt, inflation and interest rate, we estimate standard deviations and persistence of the following shocks from 2004 to 2012: monetary policy, productivity, preference, labor supply, investment cost, public spending and transfers, external assets and financial spreads, conditionally on the linearized model. ${ }^{8}$ We back out the corresponding structural shocks, extending the period to the end of 2015. Finally, we use a piecewise-linear model with two monetary policy regimes following Guerrieri and Iacoviello (2015), which we calibrate using parameters estimated on the linearized model and simulate trajectories with the estimated structural shocks. This approximation allows us to use a linear filter from 2012 to 2015 , much simpler for a model of this size. Trajectories in the baseline scenario obtained using the linearized or the piecewise-linear model are very similar.

Following this procedure, Table A2-1 in Appendix 2 shows a measure of fit for each variable, as well as the dependency of the estimation to the calibration of crucial deep parameters like the share of non-Ricardian households, the elasticities of substitution across goods and across labor inputs. The best fit is obtained with the calibration presented in Table 2 .

Underlying structural shocks, their estimated persistences and standard deviations are detailed in Table A2-2 and Figure A2-I in Appendix 2. The financial crisis impact is best characterized by a persistent and large (four standard deviations) exogenous shock on investment costs, by successive and persistent and moderate shocks on productivity (half a standard deviation),

\footnotetext{
4. Campagne and Poissonnier (2016a, 2016b) compare the simulations derived using this calibration procedure with standard DSGE models for standard transitory and/or permanent shocks. Results are in line with simulations presented in the extensive DSGE review in Coenen et al. (2012), as well as with the Insee-based macroeconometric model Mésange (Klein \& Simon, 2010).

5. If TFP growth was systematically higher in one region, it would have an infinite relative size at steady-state.

6. This debt to GDP ratio corresponds to public asset net of liabilities as a share of GDP and consequently differs from the debt in the sense of Maastricht relevant in the Stability and Growth Pact framework. However, the difference has no impact on the analysis later developed in the paper. 7. Thanks to the now famous "Whatever it takes" ECB President's speech in July 2012.

8. Although, the number of estimated parameters could be deemed as small, we show in Appendix 2 that the estimated values are robust to a number of different calibrations of other parameters. In addition, the purpose of the paper is to compute the value of shocks that brought the euro area to the ZLB at the end of 2012, and other parameters are calibrated to remain close to standard euro area DSGE models.
} 
successive and very persistent shocks on labor supply, and a very persistent and large shock on public spending. Monetary policy is considered somewhat neutral compared to the Taylor rule, over the period, despite the very low euro-wide nominal rate.

Figure I shows the trajectory under the shocks previously estimated, as well as the point at which the model enters the ZLB, denoted by the vertical line. Under that baseline scenario, output is depressed, relative to its pre-crisis trend, in both regions, as well as investment, consumption and hours worked. Public deficits are higher than their long-run average, especially in the South. Capital returns and interest rates are expected to stay low for long time.

This "baseline scenario" constitutes the central path of our simulations, around which the impact of additional fiscal shocks will be assessed, the question here being: in hindsight, knowing that the euro area economy would be stuck at the ZLB for at least three years starting from 2013, what would have been the impact of more stimulus or more fiscal consolidation?

\section{Fiscal multipliers}

The channels through which fiscal policy in one region (region A) affect output in the other region (region $\mathrm{B}$ ) are external domestic demand, monetary policy and competitiveness (see Diagram). A stimulus package directly boosts domestic demand, with a positive effect on the output of the domestic economy (region A). It also tends to have inflationary effects in the domestic economy, which may be offset

Table 1

Observed and simulated data at steady state

\begin{tabular}{|c|c|c|c|c|}
\hline \multirow{2}{*}{ in $\%$ if not specified elsewise } & \multicolumn{2}{|c|}{ Data } & \multicolumn{2}{|c|}{ Meleze } \\
\hline & North & South & North & South \\
\hline Output (GDP in billion euros) & 1,354 & 778 & 1,354 & 778 \\
\hline Output per capita average growth rate(1) & 2.3 & 1.3 & 1.9 & 1.9 \\
\hline Workin population (millions) & 76.3 & 55.1 & 76.3 & 55.1 \\
\hline Total hours worked per week (thousands) & 2,765 & 2,132 & 2,765 & 2,132 \\
\hline Gross Op. Surplus (in VA) & 44.8 & 51.8 & 42.9 & 42.9 \\
\hline Gross wages (in VA) & 54.2 & 46.7 & 42.5 & 42.5 \\
\hline Profit rate & - & - & 14.6 & 14.6 \\
\hline Nominal 3 month Euribor(1) & 3.2 & 3.2 & 3.2 & 3.2 \\
\hline Expected CPI-Inflation(1) & 1.5 & 2.5 & 1.5 & 1.5 \\
\hline Private consumption (in GDP) & 53.6 & 58.4 & 50.0 & 54.1 \\
\hline Public consumption (in GDP) & 20.1 & 18.6 & 19.9 & 18.7 \\
\hline Investment (in GDP) & 21.6 & 25.5 & 29.7 & 27.8 \\
\hline Trade balance (in GDP) & 3.9 & -2.9 & -0.1 & 0.1 \\
\hline Imports from euro area partner(2) & 4.6 & 7.7 & 5.8 & 9.5 \\
\hline PPP (GDP, normalized to 1 in the North) & 1.00 & 1.06 & 1.00 & 1.06 \\
\hline Gross consolidated general government debt (in GDP) (1) & -62.0 & -80.0 & -62.0 & -80.1 \\
\hline Private assets including firms (S1 excl. S13,) (1) & 40.0 & 5.0 & 107 & 5.6 \\
\hline Net financial position (S2) (1) & 1.0 & -53.0 & 32 & -52.0 \\
\hline Implicit tax rate on consumption & 20.6 & 17.5 & 20.6 & 17.5 \\
\hline Implicit tax rate on gross labor revenues & 38.5 & 37.0 & 38.5 & 37.0 \\
\hline Implicit tax rate on capital revenues & 26.9 & 34.5 & 25.2 & 36.3 \\
\hline Transfers (in GDP) & 15.7 & 14.1 & 28.5 & 31.2 \\
\hline
\end{tabular}

Note: North is Belgium, Germany, France and the Netherlands, South is Greece, Ireland, Italy, Spain and Portugal. S1 correspond to the whole domestic economy, S2 to the rest of the world and S13 to the public sector.

(1) indicates annualized data; (2) is measured as the share of imports from EU partners in private consumption

Sources: Eurostat, 2007 (ANA, inflation, Purchasing Power Parity (PPP), employment, Labor Force Survey), ECB average $2000-2007$ (Euribor) and Eurostat, average 2000-2010 (CPI-inflation). Authors' computations and simulations with the Meleze model for the Meleze column. 
by the central bank which sets a higher interest rate. This hike will decrease aggregate demand in both the domestic and foreign economies (resp. region $\mathrm{A}$ and region $\mathrm{B}$ ) and lead to negative spillovers. On the other hand, the resulting inflation differential, coupled with fixed nominal exchange rates, increases foreign competitiveness and in turn foreign exports.

Table 2

Key structural parameters calibration

\begin{tabular}{|c|c|c|c|c|}
\hline & & North & South & \\
\hline \multicolumn{5}{|l|}{ Union-wide } \\
\hline Technology parameter & $a$ & \multicolumn{2}{|c|}{0.498} & ANA \\
\hline Depreciation rate & $\delta$ & \multicolumn{2}{|c|}{0.016} & D'Auria et al. (2009) \\
\hline Capital rigidity & $S$ & \multicolumn{2}{|c|}{5.63} & Smets \& Wouters (2002) \\
\hline Population size & $\mathbb{N}$ & \multicolumn{2}{|c|}{131417000} & ANA \\
\hline TFP growth rate* & $g$ & \multicolumn{2}{|c|}{$1.9 \%$} & ANA \\
\hline Financial intermediation spread & $\psi^{g}, \psi$ & \multicolumn{2}{|c|}{$0.005 \%$} & Authors' computations \\
\hline \multicolumn{5}{|l|}{ Monetary policy } \\
\hline Smoothing parameter & $\rho$ & \multicolumn{2}{|c|}{0.9} & Ratto et al. (2009) \\
\hline Weight on inflation & $r_{\pi}$ & \multicolumn{2}{|c|}{1.68} & Smets \& Wouters (2003) \\
\hline \multicolumn{5}{|l|}{ Regional specific } \\
\hline Population share & $n^{i}$ & 0.58 & 0.42 & ANA \\
\hline Trade openness & $a^{i}$ & $5.8 \%$ & $9.5 \%$ & ANA, authors' computations \\
\hline Substitutability between goods & $\theta^{i}$ & 6.85 & 6.84 & D'Auria et al. (2009) \\
\hline Substitutability between workers & $\theta_{w}^{i}$ & $4.44^{\mathrm{EZC}}$ & 4.44 EZC & Bayoumi et al. (2004) \\
\hline Households adjusted discount factor & $\tilde{\beta}^{i}$ & 0.996 & 0.996 & Authors' computations \\
\hline Inverse risk aversion & $\sigma_{c}^{i}$ & $1.49 \mathrm{EZC}$ & $1.49 \mathrm{EZC}$ & Smets \& Wouters $(2002,2003)$ \\
\hline Inverse Frisch elasticity & $\sigma_{1}^{j}$ & 1.69 EZC & $1.69 \mathrm{EZC}$ & Roeger et al. (2010) \\
\hline Consumption habits & $h_{c}^{i}$ & $0.66 \mathrm{EzC}$ & $0.66^{\mathrm{EZC}}$ & Roeger et al. (2010) \\
\hline Share of non-Ricardian agents & $\mu^{i}$ & $0.31^{E Z C}$ & $0.31^{\mathrm{EZC}}$ & Roeger et al. (2010) \\
\hline Price rigidity & $\xi^{i}$ & 0.88 EZC & $0.88^{\mathrm{EZC}}$ & Coenen et al. (2008) \\
\hline Wage rigidity & $\xi_{w}^{i}$ & $0.66 \mathrm{EZC}$ & $0.66^{E Z C}$ & Eggertsson et al. (2014) \\
\hline Price indexation & $\gamma_{p}^{j}$ & $0.7^{\mathrm{EZC}}$ & $0.7^{E Z C}$ & Authors' computations \\
\hline Wage indexation & $\gamma_{w}^{i}$ & $0.8 \mathrm{EZC}$ & $0.8 \mathrm{EZC}$ & Authors' computations \\
\hline \multicolumn{5}{|l|}{ Fiscal policy } \\
\hline Budget rule sensitivity & $\rho_{g}$ & 0.012 & 0.012 & Authors' computations \\
\hline Tax rate on consumption & $\bar{v}^{c, i}$ & $20.6 \%$ & $17.5 \%$ & Eurostat (implicit tax rate) \\
\hline Tax rate on net wages & $\bar{v}^{w, i}$ & $62.5 \%$ & $58.7 \%$ & Eurostat (implicit tax rate) \\
\hline Tax rate on capital revenues & $\bar{v}^{k, i}$ & $18.5 \%$ & $25.7 \%$ & Eurostat (implicit tax rate) \\
\hline Transfers to GDP ratio & $\bar{\Phi}^{i}$ & $27.8 \%$ & $31.3 \%$ & Authors' computations \\
\hline \multicolumn{5}{|l|}{ Government's objective (see section 6) } \\
\hline Preference for spending-based consolidation & $\lambda_{g}^{i}$ & 0.34 & 0.37 & Authors' computations \\
\hline Preference for VAT-based consolidation & $\lambda_{c}^{i}$ & 0.47 & 0.48 & Authors' computations \\
\hline Output smoothing & $\sigma_{y}$ & 1 & 1 & Authors' assumption \\
\hline Deficit smoothing & $\sigma_{p b}$ & 5 & 5 & Authors' assumption \\
\hline
\end{tabular}

Note: ANA stands for Annual National Accounting data from Eurostat in 2007. Author's computations correspond to values determined by inverse inference as explained in the text. Papers cited for calibration are given as an example of a paper close to the median of our literature review. EZC stands for euro area Calibration and corresponds to parameters calibrated on euro area data in the absence of adequate region-specific information. North represents Belgium, Germany, France and the Netherlands, whereas South includes Greece, Ireland, Italy, Spain and Portugal. Parameters name are those in Campagne and Poissonnier (2016). 
The positive effect on domestic demand (region A) also increases foreign exports, leading to positive spillovers. The net effect on foreign output is negative when the inflationary effect of fiscal policy and of the subsequent monetary contraction dominates its effect on domestic import demand.

Figures II and III display the impact and cumulative marginal multipliers of spending-based and VAT-based temporary ${ }^{9}$ fiscal consolidations of different sizes on domestic and foreign output, under the two cases, as deviations around the baseline scenario outlined above. As detailed in Campagne and Poissonnier (2016b) for the purely linear case, those multipliers compare with those obtained in most institutional DSGE models as well as with macroeconometric models. ${ }^{10}$

First, as expected, in the case of stimulus packages big enough to immediately lift the Euro Area out of the ZLB, the marginal effect of the last unit spent or raised is constant. In the case of spending shocks, the impact multiplier is around 1.1 while the 3 -years average multiplier is comprised between 0.4 and 0.5 . The effect on foreign output, yet relatively small, goes opposite to domestic consolidation or expansion in the short and medium run reflecting that, with our calibrations and our assumption that public consumption is entirely domestic, the monetary offset effect is higher than the external demand effect: if the North implements a spending-based deficit reduction outside the ZLB, the subsequent decrease in the interest rate by the central bank dominates and favors activity in the South.

In the case of VAT shocks outside the ZLB, impact and cumulative multipliers are similar and around 0.5 at impact. Spillovers on foreign output (region B) go in the same direction as Northern output (region A) and are negligible on impact. This results from the fact that VAT increases are less deflationary than spending cuts, and also that their effect on consumption has a bigger impact on external demand, both tending to correlate the domestic and the foreign effect. However, over three years, spillovers are weaker than for public spending cuts and even slightly negative.

Second, at the ZLB, the marginal effect of fiscal policy on domestic as well as foreign output changes. Spending cuts tend to have an increasing negative effect on the domestic output and a negative and increasing effect on the foreign output. In the case of VAT shocks, the effect is even stronger.
Figures A3-I and A3-II in Appendix 3 show that the spillovers, i.e. the marginal multiplier on foreign output (region $\mathrm{B}$ ) relative to the marginal multiplier on domestic output (region A), increase significantly with the size of the consolidation package, a conclusion that is robust to several calibrations. In particular, the marginal effect of big VAT-based consolidation in the North on the South's output is between 20\% and $50 \%$ of the domestic effect, compared to only $-20 \%$ in the linear case. Cooperative governments will take this externality into account.

As mentioned earlier, those public spending multipliers rely on the simplifying assumption that public consumption gathers the whole public spending while in the current context of low TFP growth in the euro area, international institutions advise changes in the composition of public spending in order to favor public investment and support potential growth. In the long run, public investment shocks are indeed expected to have higher multipliers than public consumption.

However, in the short run, fiscal multipliers tend to be close (Coenen et al., 2012) and the productivity boost of public investment with respect to public consumption materializes slowly (around five years in Abiad et al. (2015) or using the European Commission Quest III model). The present paper focusing on short-lived and transitory fiscal behaviors, we can expect to obtain similar results with public investment over the short and medium term, as transmissions channels would not differ significantly. In particular, our model remains focused on business cycles and does not include endogenous growth mechanisms that would allow higher long-term fiscal multipliers of public investment.

\section{Policy coordination}

\section{Policy objective}

Regional governments are expected to obey a simple budget rule linking current public consumption to past level of public debt, with the sole objective to stabilize the debt-to-GDP ratio around its steady-state level. However, the realism of such a rule might be questioned when large shocks occur. Following the 2008 crisis,

\footnotetext{
9. with an average duration of twelve quarters.

10. See Coenen et al. (2012) for a thorough comparison of fiscal multipliers across IMF, OCDE, and central banks' DSGE models, and Klein and Simon (2010) for the French macroeconometric model Mésange.
} 
governments in the euro area implemented successive additional fiscal plans. This suggests that, given their national preferences and the global environment, governments may choose to foster activity at the cost of debt convergence or, on the contrary, to achieve a faster debt convergence at the expense of activity.

Our goal is to analyze how governments in each region could have decided to accelerate or reduce the pace of debt convergence by implementing additional fiscal policies when the ZLB was reached. For illustrative and simplification purposes, we consider that fiscal policies take the form of a temporary public consumption or VAT shock, starting in 2013. Shocks follow an auto-regressive process with a persistence calibrated as to amount to an average duration of twelve quarters.

In order to model governments' behaviors, we focus on a policy approach based on the

Figure I

\section{Baseline scenario}

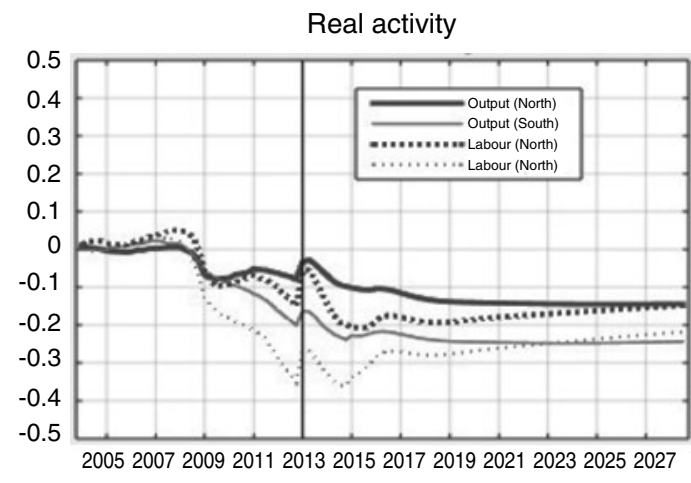

Final demand
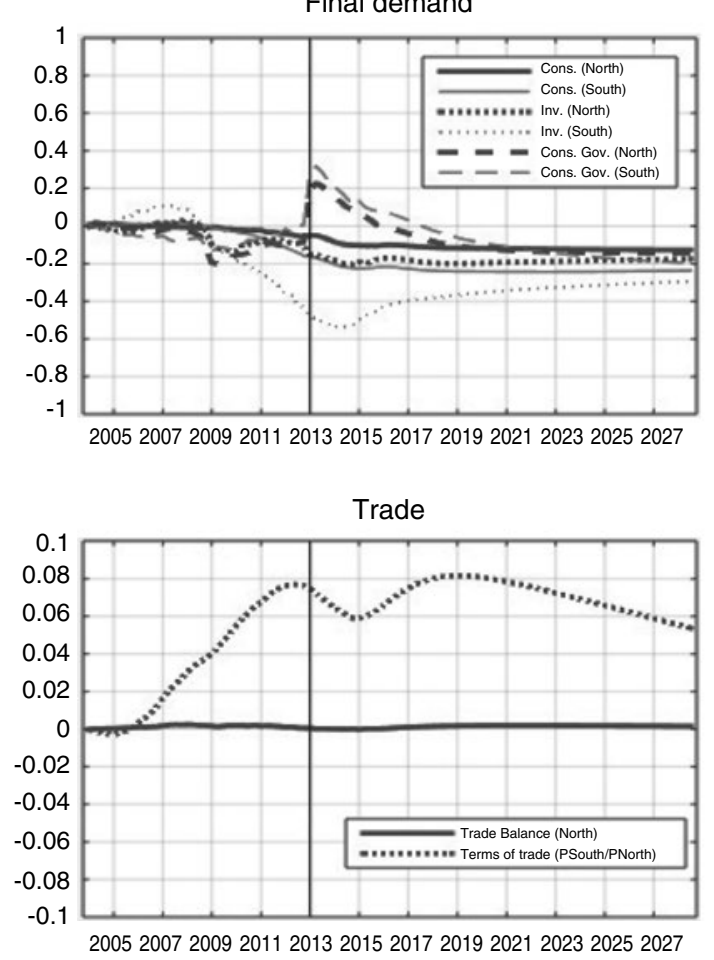

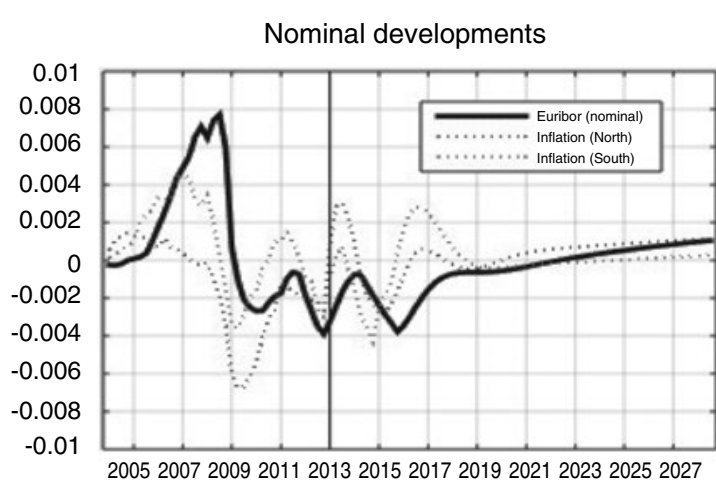

Prod. factor cost

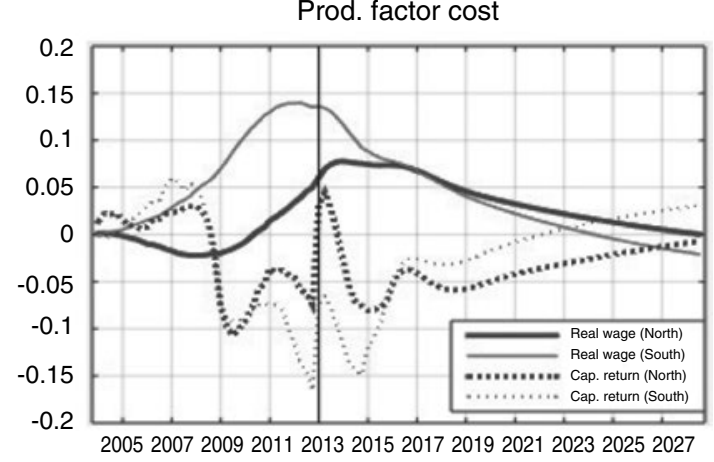

Public Deficit

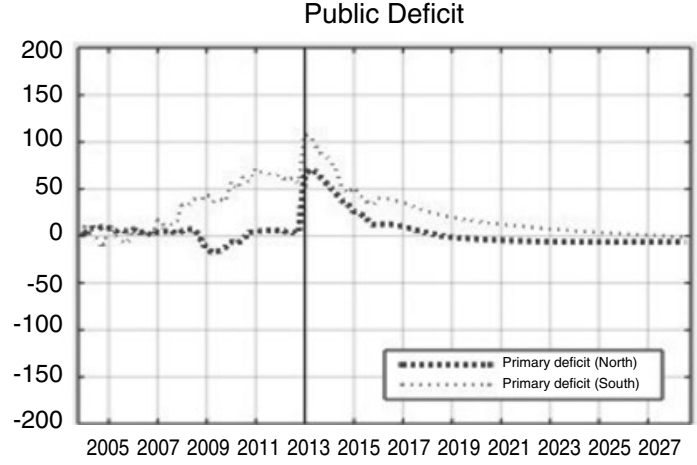

Note: North represents Belgium, Germany, France and the Netherlands, whereas South includes Greece, Ireland, Italy, Spain and Portugal. The trajectories correspond to the simulation around the steady state using estimated structural shocks. Y-axes are in \% deviations from the steady state. Reading note: at the beginning of 2013 , activity declined by $0.2 \%$ in the South region with respect to its steady state value, whereas public consumption increased by $0.2 \%$.

Source: Authors' computations. Simulations with the Meleze model. 
definition of an objective function for the government weighting its preference for deficit reduction against activity. We assume governments maximize an objective function (or minimize a loss function). We consider a static game, meaning that the government decides in 2013Q1 which fiscal unexpected shock will be implemented, while agents in the model do not expect the government to act strategically.

We assume that there exists a trade-off between fostering activity and reducing the deficit. However, the definition of such preferences is a difficult task and relates to the construction of an adequate objective function for the fiscal authorities, analogous to the central bank loss function used to derive optimal Taylor rules (Gali, 2008). We argue that a reasonable objective function needs to comply with a few constraints or expected properties: $(i)$ it increases with activity, (ii) it decreases with the public deficit, (iii) it should not "unreasonably" favor one objective over the other, (iv) the government tries to smooth both its deficit and activity over the medium-term.

The two first properties represent the trade-off between fostering activity and improving debt sustainability. The third property relates to the fact that governments will not seek to boost activity by such an amount that the debt will explode, and vice versa. The fourth property ensures that the further a deviation from the steady state, the costlier it is. We also assume that spending-based and VAT-based consolidation have separable effects on governments' payoffs.

Having in mind all of these suitable properties, we assume government $i$ will seek to maximize the static payoff $V^{i}$, choosing public consumption and VAT surprise shocks leading to a $e x$ ante deficit reduction of respectively $v^{g} \%$ and $v^{c} \%$ of GDP:

$$
\begin{aligned}
V^{i}\left(v^{g}+v^{c}\right)= & \sum_{t=0}^{H} \frac{\left[1+\bar{y}_{t}^{i}\left(v^{g}, v^{c}\right)\right]^{1-\sigma_{y}}+1}{1-\sigma_{y}} \\
& +\lambda_{i}^{g} \cdot \frac{\left[1+\bar{p} b \bar{p} b_{t}^{i}\left(v^{g}\right)\right]^{1-\sigma_{p b}}+1}{1-\sigma_{p b}} \\
& +\lambda_{c}^{i} \cdot \frac{\left[1+\bar{p} b \bar{p} b_{t}^{i}\left(v^{c}\right)\right]^{1-\sigma_{p b}}+1}{1-\sigma_{p b}}
\end{aligned}
$$

where $\bar{y}\left(v^{g}, v^{c}\right)$ is the deviation of output from its steady state level, $\bar{p} b \bar{p} b\left(v^{g}\right)$ (resp. $\bar{p} b \bar{p} b\left(v^{c}\right)$ ) is the spending-based (resp. VAT-based) deviation of primary balance from steady state, expressed in unit of GDP. The parameter $\lambda_{g}^{i}$ (resp. $\lambda_{c}^{i}$ ) defines the preference for spending-based (resp. VAT-based) fiscal consolidation and $H$ is both the expected length of the fiscal policy and the government's objective horizon, here twelve quarters. Finally, $\sigma_{y}$ and $\sigma_{p b}$ define each government's smoothing preference.

Diagram

Three propagation channels for spillovers of fiscal policy

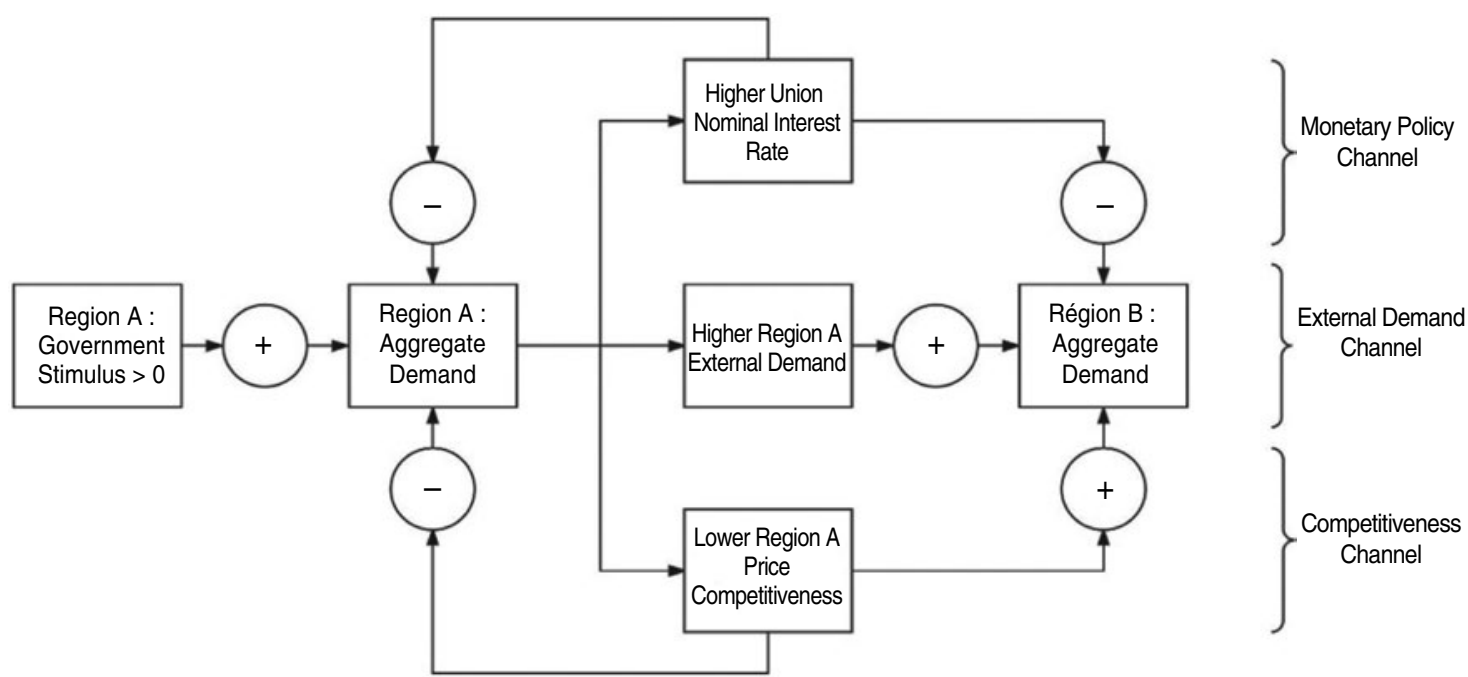


Lacking appropriate data to calibrate the parameters $\lambda_{g}^{i}$ and $\lambda_{c}^{i}$, we assume that governments have no incentive to deviate from the budget rule when the economy is at the steady state. Namely, in the absence of shocks, we assume that governments will hold to the budget rule and choose to maintain a debt to GDP ratio at its target. This assumption implies that, in the vicinity of the steady state, $\partial V / \partial v^{j}\left(v^{j}=0, v^{-j}=0\right)=0$. In other words, the marginal effects on the government payoff of a public consumption shock $v^{g}$ (resp. of a VAT shock $v^{c}$ ) cancel each other for $\lambda_{j}^{i}$ given by:

$$
\lambda_{j}^{i}=\left(\sum_{t=0}^{H} \frac{\partial \hat{y}_{t}^{i}}{\partial v}\left(v^{j}=0, v^{-j}=0\right)\right)\left(\sum_{t=0}^{H} \frac{\partial \hat{p} b_{t}^{i}}{\partial v^{j}}\left(v^{j}=0\right)\right)^{-1}
$$

Figure II

\section{Marginal fiscal multipliers of spending-based consolidation}

in deviation from the baseline scenario, in \%

1st quarter, multiplier on domestic GDP

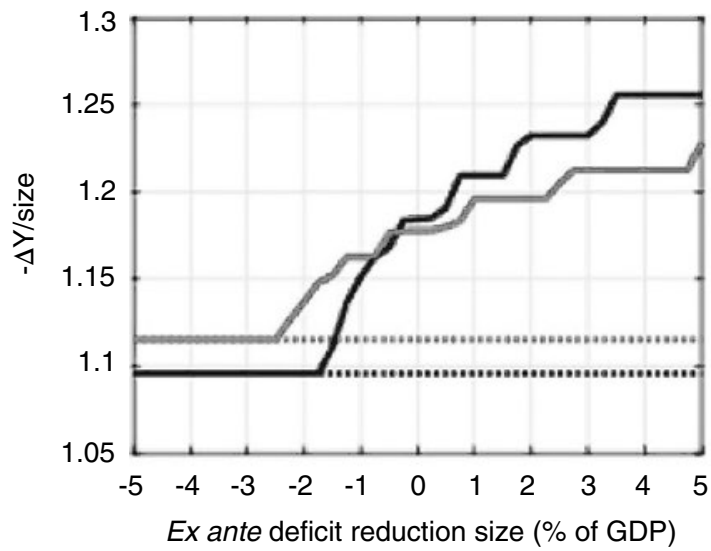

1st quarter, multiplier on foreign GDP

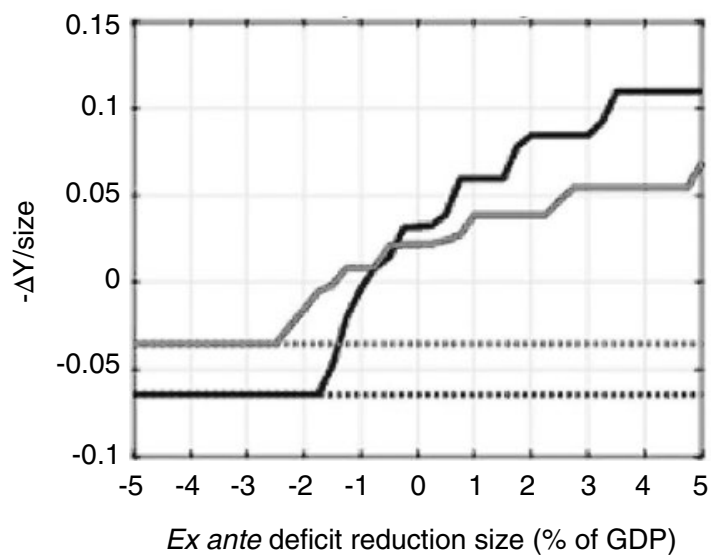

3 year average, multiplier on domestic GDP

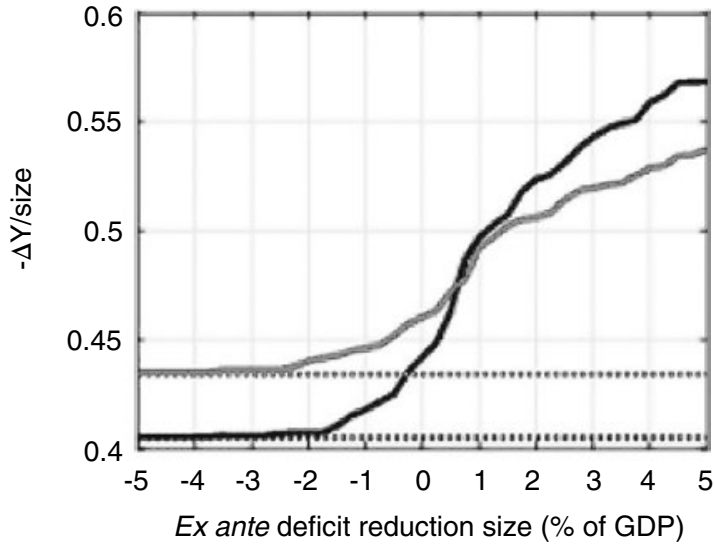

3 year average, multiplier on foreign GDP

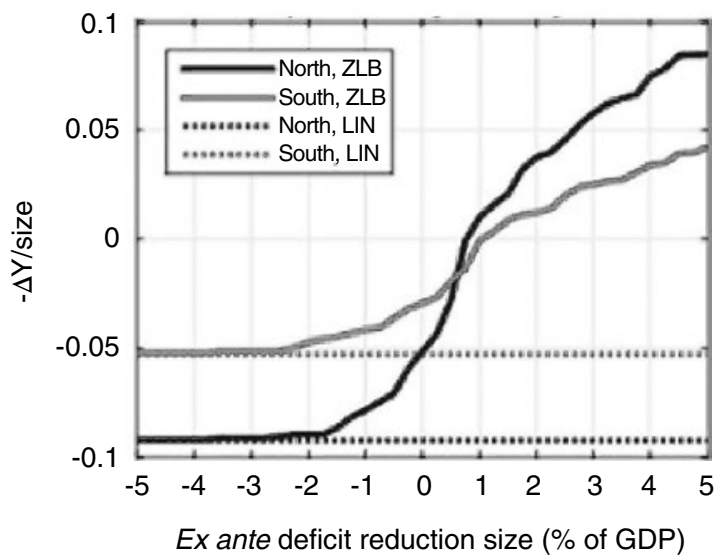

Note: Effects are normalized as the ratio of the marginal effect on output of the additional fiscal shock to its ex-ante size as a percentage of domestic GDP. Responses to a fiscal shock in the North are in black, to a fiscal shock in the South are in grey. Dotted lines (LIN) corresponds to multipliers in the linear case, whereas solid lines (ZLB) corresponds to the existence of a zero lower bound. Lastly, "1st quarter" corresponds to the impact multiplier, whereas "3-year average" corresponds to a multiplier computed over three years. Lower spillovers from Southern fiscal shocks partly relates to the smaller size of the South region. These figures read like regular multiplier: when positive, the effect of a consolidation on domestic (resp. foreign) output is negative.

Reading note: When the ZLB binds (solid lines), an ex ante 4\% GDP of spending-based fiscal consolidation (ie. deficit reduction) in the North region (black lines) implies that an additional euro of deficit reduction leads to a a 1.25 euros decrease of North activity during the first quarter (top left panel), and a 0.55 euros decrease on average over three years (top right panel). In the South, spillovers induce an activity slowdown of slightly more than 0.1 euros of North GDP during the first quarter (bottom left panel), and of 0.075 euros on average over three years (bottom left panel). In other words, this means that spillovers amount to $7.5 \%$ to $10 \%$ of the input shock.

Source: Authors' computations. Simulations with the Meleze model. 
The resulting calibrated values of $\lambda^{i}$ for each government are shown in Table 2. A calibrated value of around $1 / 3$ means that at the steady state, the payoff of a 3-percentage points improvement in the primary deficit or a 1-percentage point improvement in output is the same. Since the $\lambda^{i}$ are calibrated as to maximize the governments payoff at the steady state, they depend on the government spending marginal multiplier at the steady-state and the elasticity of the primary deficit to output. We assume a log-utility for output $\left(\sigma_{y}=1\right)$ and calibrate $\sigma_{p b}=5$ as the minimum value leading to interior solutions in the allowed

Figure III

Marginal fiscal multipliers of VAT-based consolidation

in deviation from the baseline scenario, in \%
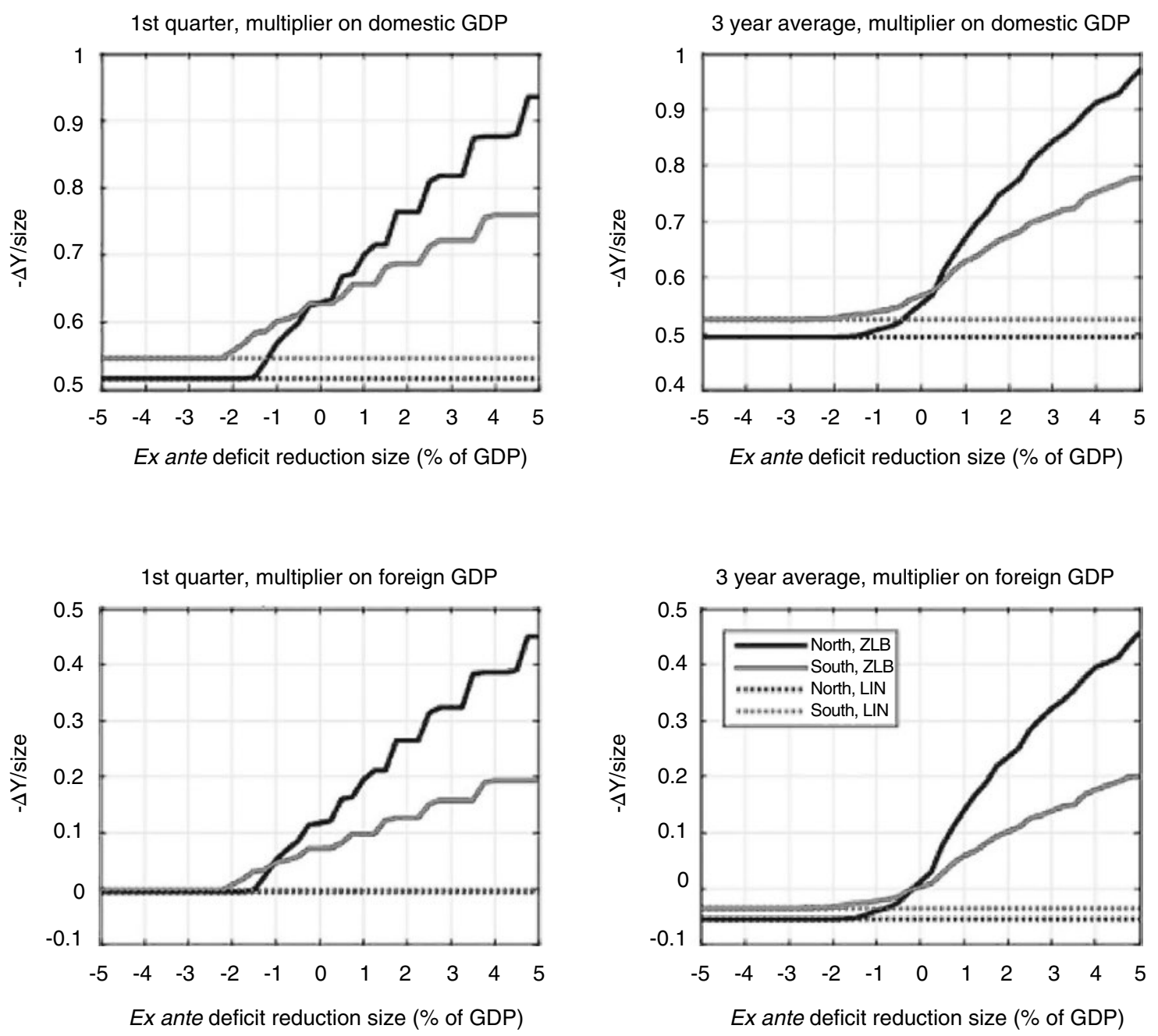

Note: Effects are normalized as the ratio of the marginal effect on output of the additional fiscal shock to its ex-ante size as a percentage of domestic GDP. Responses to a fiscal shock in the North are in black, to a fiscal shock in the South are in grey. Dotted lines (LIN) corresponds to multipliers in the linear case, whereas solid lines (ZLB) corresponds to the existence of a zero lower bound. Lastly, "1st quarter" corresponds to the impact multiplier, whereas "3-year average" corresponds to a multiplier computed over three years. Lower spillovers from southern fiscal shocks partly relates to the smaller size of the South region. These figures read like regular multiplier: when positive, the effect of a consolidation on domestic (resp. foreign) output is negative.

Reading note: When the ZLB binds (solid lines), an ex ante 4\% GDP of VAT-based fiscal consolidation (ie. deficit reduction) in the North region (black lines) implies that an additional euro of deficit reduction leads to a slightly less than 0.9 euros decrease of North activity during the first quarter (top left panel), and a slightly more than 0.9 euros decrease on average over three years (top right panel). In the South, spillovers induce an activity slowdown of 0.4 euros during the first quarter (bottom left panel), and of 0.4 euros on average over three years (bottom left panel). In other words, this means that spillovers amount to $40 \%$ of the input shock.

Source: Authors' computations. Simulations with the Meleze model. 
range of possible fiscal shocks (ie. ex ante deficit reduction of $-5 \%$ to $+5 \%$ of GDP).

\section{Optimal Policy}

As shown above, there are union-wide spillovers from regional fiscal policies. Therefore, there is room for strategic interactions within the monetary union. Outside the ZLB, and following consolidation package in the North, expansionary monetary policy will have positive effects in the South, and governments' objectives will diverge. However negative spillovers will prevail at the ZLB and regional objectives will converge. The optimal amount of coordination will thus differ whether monetary policy can or cannot react.

As in Mendoza et al. (2014), we study the solutions to one-shot cooperative and non-cooperative games defined as follows. ${ }^{11}$ The strategy space is defined in terms of pairs of instrument values $\left(v^{N}, v^{S}\right)$ chosen by regional governments. ${ }^{12}$ As explained in the previous section, the game is static with payoffs taking into account the dynamic of the economy over a horizon of twelve quarters. We also assume than the strategy space does not include the possibility of transfers from one region's government to the other. Each regional government chooses its instrument value so as to maximize the objective functions $V^{i}$ as defined earlier. Given the decision $v^{j}$ of the region $j$ 's government, the best response of region $i$ is given by:

$v^{i, *}\left(v^{j}\right)=\underset{v^{i}}{\arg \max } V^{i}\left(v^{i} \mid v^{j}\right)$

The Nash non-cooperative equilibrium is therefore given by the intersection of both best response curves at $\left(v^{N, *}\left(v^{S, *}\right), v^{S,{ }^{*}}\left(v^{N, *}\right)\right)$. We define the cooperative equilibrium as the solution from the optimization program of a union-wide social planner with the following payoff:

$$
\omega V^{N}\left(\tau^{N} \mid \tau^{S}\right)+(1-\omega) V^{S}\left(\tau^{S} \mid \tau^{N}\right)
$$

where $\omega$ defines the weight attributed to the North region. Our central assumption is that regions are weighted according to their population share (that is 58\% for the North and $42 \%$ for the South), but this may not always be the case and therefore, multiple cooperative equilibrium can be sustained for different values of $\omega$.
Each of these cooperative equilibria is said to be sustainable if and only if both regions are at least as well off as under the Nash equilibrium. Although each decision maker will have an idiosyncratic incentive to deviate from the coordinated policy, we assume that they expect that themselves deviating will result in the other decision maker also deviating. Both decision makers agree to stay at the cooperative equilibrium if they are both better-off by doing so.

In practice, since our solution is non-linear, we only solve for solutions on a discrete grid. At each node $\left(v^{N}, v^{S}\right)$ within a given set of potential fiscal shocks ranging from ex ante deficit reductions of $-5 \%$ to $+5 \%$ of GDP), we simulate the trajectory of the economy and compute the values of Northern and Southern objective functions.

Note that for all the following figures, shocks are expressed (and grid is indexed) by this $e x$ ante effect on the deficit expressed in \% of GDP.

\section{Strategic vs cooperative game}

Figure IV displays each regional governments' payoff (that is, the value of the objective function) for the two fiscal shocks of interest, and their best responses to each possible action of the other government. ${ }^{13}$

Those first figures can be analyzed along three dimensions:

1. For a given action of a foreign government, what is the optimal domestic strategy?

2. How does that optimal domestic strategy vary with the foreign government's action?

3. What is the combination of shocks that maximizes the domestic government's payoff?

Consider spending shocks from the point of view of the North region (top left panel). If the South chooses inaction, the optimal action of the North is to implement a small stimulus package, of around $1.5 \%$ of GDP. This choice (i.e. the value of the curve's $\mathrm{x}$-intercept) depends on the North's preference for

11. We keep the notations of Mendoza et al. (2014).

12. For simplification purposes, we suppose that governments use only one instrument at a time, that is $\left(v^{N}, v^{S}\right)=\left(v^{N, g}, v^{S, g}\right)$ or $\left(v^{N}, v^{S}\right)=\left(v^{N, c}\right.$ $\left.v^{S, c}\right)$, making the policy space two-dimensional.

13. The action $\left(v^{N}, v^{s}\right)=(0,0)$ corresponds to the baseline scenario detailed in Figure 1. 
A: Spending Shock, 'North' Objective and Best Response ZLB

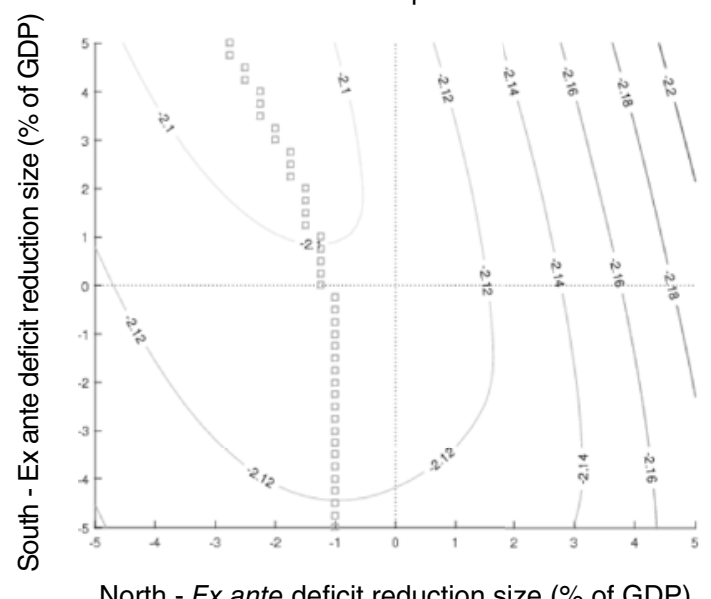

C: VAT Shock, 'North' Objective

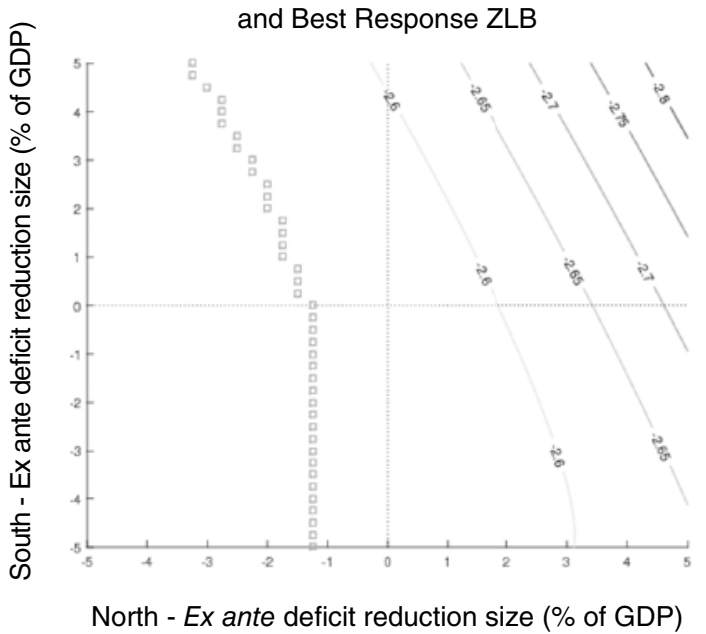

B: Spending Shock, 'South' Objective and Best Response ZLB

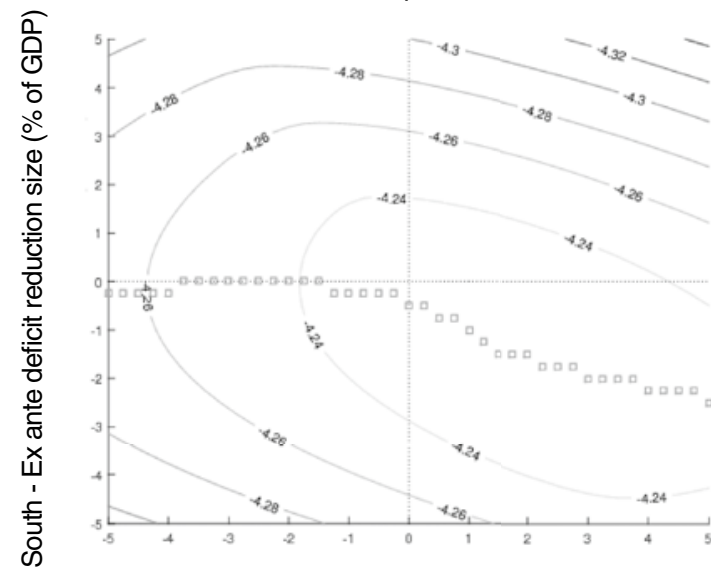

North - Ex ante deficit reduction size (\% of GDP)

D: VAT Shock, 'South' Objective

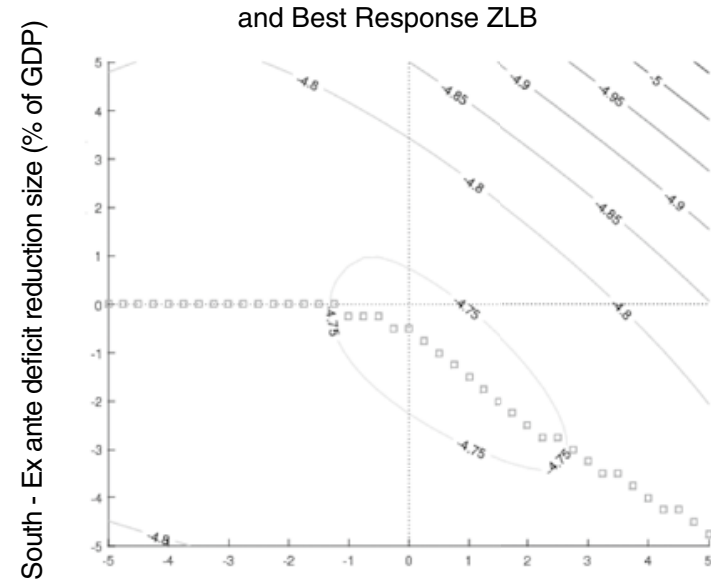

North - Ex ante deficit reduction size (\% of GDP)

Note: Governments' objectives being surfaces, they are displayed through multiple iso-payoff curves. Squares are best responses.

Reading note: Considering VAT as the sole fiscal policy instrument for both regions (bottom panels), if the South region is expected to reduce its deficit by $2 \%$ of its GDP, the optimal behavior of the North region (left panel) is to increase its deficit by $2 \%$ of its GDP by lowering VAT taxes. This corresponds to the maximum of the objective function on the horizontal $2 \%$ line corresponding to the expected behavior of the South region. Source: Authors' computations. Simulations with the Meleze model.

consolidation: both output and public balance were below their long-term value, the North has to choose which it favors. Moreover, the more the South chooses to consolidate (moving upward on the figure), the more deflationary pressures to the economies and the longer the duration of the ZLB. Therefore, a domestic consolidation package would become costlier to the North. Hence, North's optimal choice shifts to the left on the figure, towards a bigger stimulus package, and the overall best response slope for the North region is negative. Finally, as spending-based consolidations tend to have positive (but decreasing) spillovers inside the ZLB, the global maximum of the North's payoff function is obtained when the South consolidates a lot and the North compensates by stimulating. This global maximum is out of the range of allowed fiscal shocks. A symmetric behavior is observed for the South region. Consequently, the uncoordinated equilibrium is to increase spending by $1.25 \%$ of GDP in the North and increase spending by $0.25 \%$ of GDP in the South. Considering VAT shocks, the form of the best responses of North and South region are similar: due to the positive spillovers of VAT shocks, the North 
chooses stimulus packages when the South consolidates a lot, and the situation is symmetric for the South.

Now, superposing both best responses, Figure V compares the resulting Nash equilibrium to the optimal coordination equilibrium, and assesses the sustainability of the coordination equilibrium under different weights attributed to each region. Panels on the left display the average objective of the entire monetary union when each region are weighed according to their population share, and compares it to the strategic interaction. In both case (public spending or VAT shock), the optimal and strategic equilibria are close, translating the fact that when foreign

Figure $\mathrm{V}$

Uncoordinated vs cooperative equilibria at the ZLB

A: Spending Shock, euro area Objective,

Best Responses vs Cooperative Equilibrium, ZLB

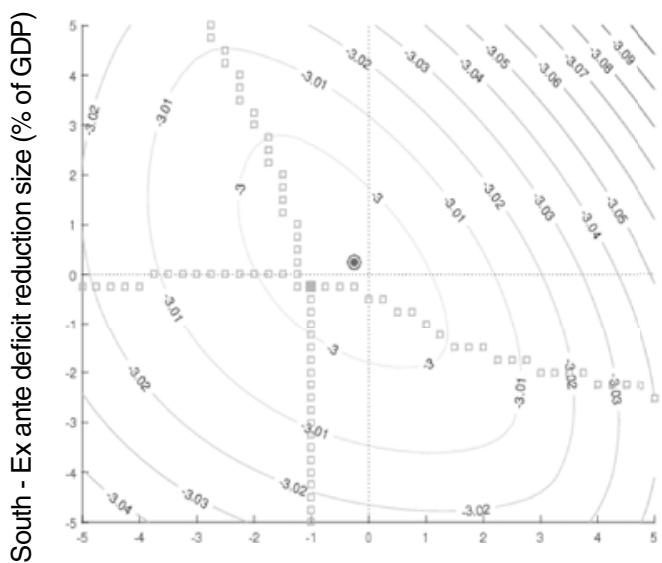

North - Ex ante deficit reduction size (\% of GDP)

C: VAT Shock, euro area Objective,

Best Responses vs Cooperative Equilibrium, ZLB

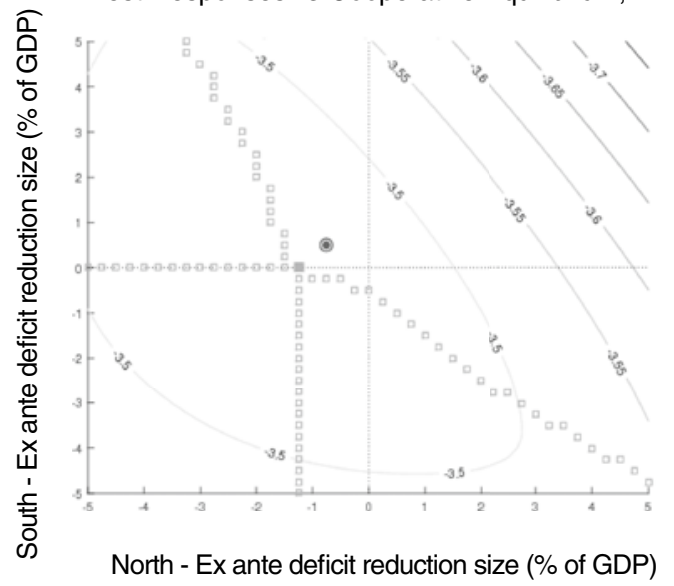

B: Spending Shock, Cooperative equilibria,

Cooperative equilibrium stability, ZLB

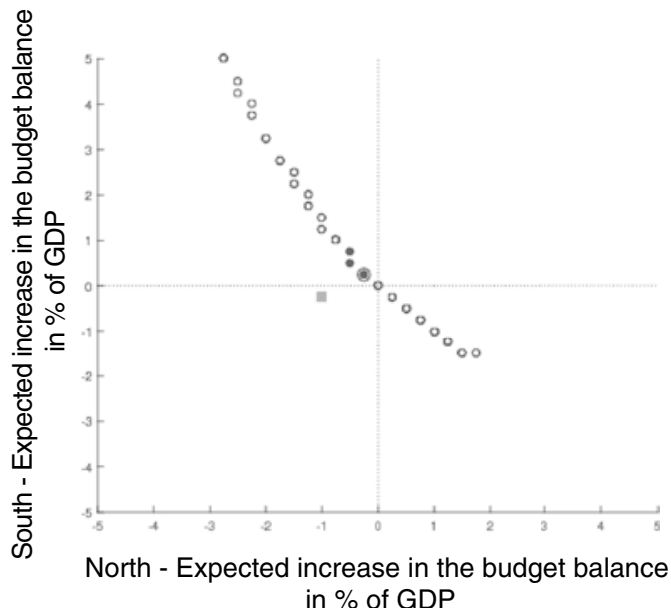

D: VAT Shock, Cooperative equilibria,

Cooperative equilibrium stability, ZLB

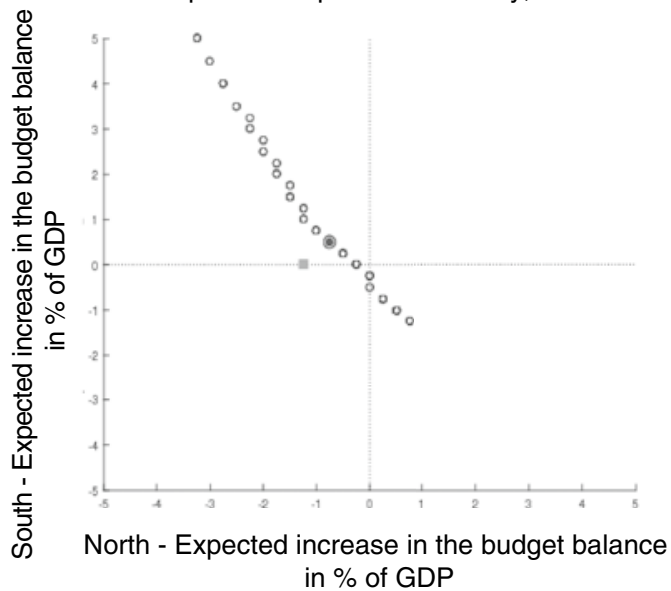

Note: On the left figures, the euro area aggregate (cooperative) objective being a surface, it is displayed through multiple iso-payoff curves. Uncoordinated strategic interactions are represented by empty squares for best responses. The Nash equilibrium corresponds to the filled square. The cooperative equilibrium using population weights is indicated by the circle. On the right figures, the weight associated to the North region in the aggregate cooperative objective varies from 0 to 1 , and the corresponding cooperative equilibrium are still represented by circles. Full circles are sustainable equilibria; empty circles are unsustainable equilibria.

Reading note: When the ZLB exists, considering public spending as the sole fiscal policy instrument for both regions (top panels), the optimal behavior of a euro area wide government is to increase spending by $0.3 \%$ of GDP in the North and to decrease spending by $0.3 \%$ of GDP in the South (left panel, filled circle as the global maximum of the objective function whose iso-payoff curves are displayed). The uncoordinated policy is to increase spending by $1.3 \%$ of GDP in the North and increasing spending by $0.3 \%$ in the South (left panel, filled square corresponding to the intersection of best response curves displayed on Figure $\mathrm{V}$ )

Source: Authors' computations. Simulations with the Meleze model. 
and domestic are similarly impacted by a domestic package, uncoordinated policies tend to be closer to the optimum. Given the level of output and primary deficit in 2013Q1 (compared to the steady state), optima tend to be in the upper left quadrant, which means more fiscal stimulus in the North and more fiscal consolidation in the South than in the baseline scenario. The panels on the right show that for regions weights that are close to the population share, the cooperative equilibrium is sustainable.

By comparison, Figure VI shows the same graphs, with the same calibration but in the case where monetary policy is never constrained by the ZLB. In that case, spillovers are smaller or

Figure VI

Uncoordinated vs cooperative equilibrium outside the ZLB

A: Spending Shock, euro area Objective,

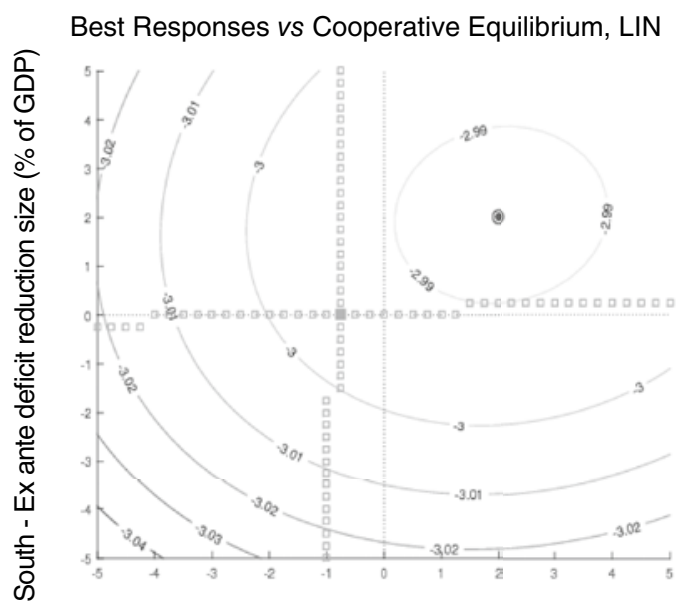

North - Ex ante deficit reduction size (\% of GDP)

C: VAT Shock, euro area Objective,

Best Responses vs Cooperative Equilibrium, LIN

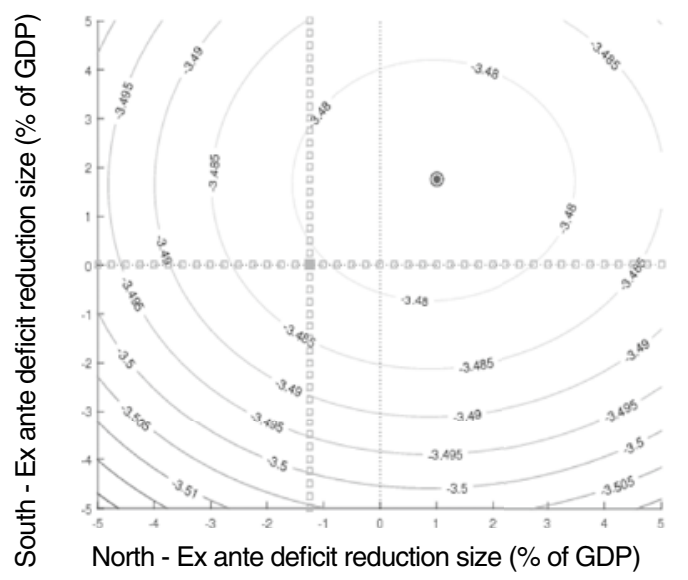

B: Spending Shock, Cooperative equilibria,

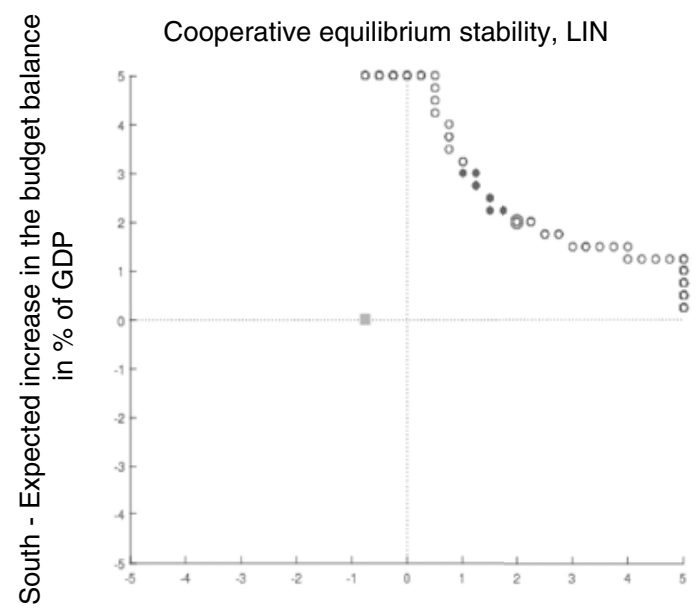

North - Expected increase in the budget balance in \% of GDP

D: VAT Shock, Cooperative equilibria,

Cooperative equilibrium stability, LIN

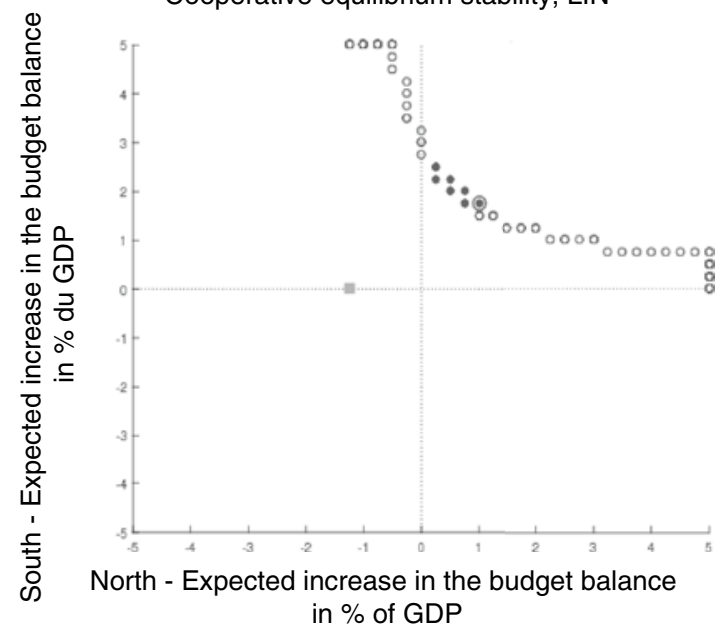

Note: On the left figures, the euro area aggregate (cooperative) objective being a surface, it is displayed through multiple iso-payoff curves. Uncoordinated strategic interactions are represented by empty squares for best responses. The Nash equilibrium corresponds to the filled square. The cooperative equilibrium using population weights is indicated by the circle. On the right figures, the weight associated to the North region in the aggregate cooperative objective varies from 0 to 1 , and the corresponding cooperative equilibrium are still represented by circles. Full circles are sustainable equilibria; empty circles are unsustainable equilibria.

Reading note: Outside the ZLB, considering public spending as the sole fiscal policy instrument for both regions (top panels), the optimal behavior of a euro area wide government is to decrease spending by $2 \%$ of GDP in both regions (left panel, filled circle as the global maximum of the objective function whose iso-payoff curves are displayed). The uncoordinated policy is to increase spending by $0.8 \%$ of GDP in the North with no action in the South (left panel, filled square corresponding to the intersection of best response curves displayed on Figure V).

Source: Authors' computations. Simulations with the Meleze model. 
negative, and best responses are less reactive. Indeed, when foreign actions by the other government do not affect significantly the domestic multiplier, the optimal choice by the domestic government mostly depends on this domestic trade-off between fiscal consolidation and activity fostering policies. Moreover, when spillovers are small or slightly negative, coordinating fiscal policies becomes preferable. Consequently, outside the ZLB and in the spending public case, the uncoordinated equilibrium would be to increase spending by $1 \%$ of GDP in the North and do nothing in the South. The North-East location of the cooperative equilibrium with respect to the Nash equilibrium means that both regions would prefer the other region to consolidate more.

Outside the ZLB, the cooperative equilibrium is "far" from the Nash equilibrium. Given negative spillovers of fiscal expansion in one region due to the monetary contraction, each region wishes its partner to consolidate, so as to benefit from the resulting expansionary monetary policy. Coordination would therefore lead to more consolidation by both regions than their natural tendency to do so. Stated in terms of our government objectives, the loss implied by the stronger consolidation in one region will be offset by the partner's stronger consolidation, and therefore be smaller than at the Nash equilibrium. All in all, both regions will be better off at the cooperative equilibrium.

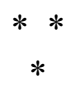

Using the Mélèze fiscal DSGE model developed at Insee and estimating structural shocks to replicate the conditions where, absent any additional shock, the Euro Area would have been stuck at the ZLB for three year starting in 2013, we have shown that in a monetary union, when monetary policy is constrained by a ZLB episode and the duration of this episode is endogenous, domestic effects of fiscal policy on output are in general much larger than when monetary policy is unconstrained.

Second, spillover effects from fiscal policy are substantially higher at the margin when monetary policy is constrained than when it is not. Increasing with the size of fiscal consolidation measures, spillover effects at the impact can amount up to $15 \%$ of the domestic impact in the case of spending-based consolidations, and to $50 \%$ of the domestic impact in the case of VAT-based consolidations.

Outside the ZLB, there are gains from fiscal coordination across regions as consolidation in one region benefits to the activity of the other region due to the reaction of monetary policy. At the ZLB however, national objectives tend to be closely related and there are fewer gains from consolidation. The existence of a ZLB and consequently of higher spillovers implying closer regional and union-wide objectives implies that one of the rationales behind coordination of fiscal policies by external fiscal rules such as the Stability and Growth Pact is less stringent in the latest economic environment. However, as the recovery strengthens in the Euro Area, and as the normalization of monetary policy is closing in, divergence across national objectives will gradually increase, as well as gains from cooperation. Therefore, a thorough and in-depth reflection could be engaged on the design and the implementation of fiscal rules in the EU.

This sets path for future research on the means to improve fiscal policies interactions in the euro area. Within the scope of the current paper, future work will focus on the study of more detailed fiscal packages allowing for shocks of different duration across regions, possibly permanent, or for mixed packages combining both tax and spending-based stimulus. One main limit of our analysis is the fact that most structural parameters are calibrated. This could be improved, notably by estimating the share of financially-constrained households, likely to play a significant role in the dynamic during the recession.

Lastly, going beyond the retrospective analysis of the 2008 crisis and going forward, in the latest environment of low growth, focusing on permanent fiscal shocks should also require addressing the impact of the composition of public expenditures and revenues on potential TFP growth. As international organizations are now calling for more public investment expenditure, distinguishing between public consumption and investment in the present model will be key first steps. 
Abiad, M. A., Furceri, D. \& Topalova, P. (2015). The macroeconomic effects of public investment: Evidence from advanced economies. International Monetary Fund, Document de travail $\mathrm{N}^{\circ} 15 / 95$. https://www.imf.org/external/pubs/cat/longres. aspx?sk=42892.0

Annicchiarico, B., Di Dio, F. \& Felici, F. (2013). Structural reforms and the potential effects on the Italian economy. Journal of Policy Modeling, 35(1), 88-109.

https://doi.org/10.1016/j.jpolmod.2012.03.002

Auray, S., Eyquem, A., \& Gomme, P. (2012). A Tale of Tax Policies in Open Economies. Working Paper, Retrieved from

https://halshs.archives-ouvertes.fr/halshs-00655931

Bayoumi, T., Laxton, D. \& Pesenti, P. (2004). Benefits and Spillovers of Greater Competition in Europe: A Macroeconomic Assessment. ECB Working Paper $\mathrm{N}^{\circ} 341$.

https://www.ecb.europa.eu/pub/pdf/scpwps/ ecbwp341.pdf?6862a0ff5c6eac71887e7dbd58c8 $54 \mathrm{e} 5$

Cacciatore, M., Duval, R. \& Fiori, G. (2012). Short-Term Gain or Pain? A DSGE Model-Based Analysis of the Short-Term Effects of Structural Reforms in Labour and Product Markets. OECD Economics Department Working Papers N 948. https://doi.org/10.1787/5k9csvkkr3xn-en

Calvo, G. A. (1983). Staggered prices in a utility-maximizing framework. Journal of Monetary Economics, 12(3), 383-398.

https://doi.org/10.1016/0304-3932(83)90060-0

Campagne, B.\& Poissonnier, A. (2016a). MELEZE, a DSGE model for France within the Euro Area. Insee- Dese, Document de travail $\mathrm{N}^{\circ} \mathrm{G} 2016 / 05$. https://www.insee.fr/en/statistiques/2022156

Campagne, B. \& Poissonnier, A. (2016b). Laffer curves and fiscal multipliers: lessons from a DSGE model. INSEE, DESE, Document de travail $\mathrm{N}^{\circ} \mathrm{G} 2016 / 06$.

https://www.insee.fr/en/statistiques/2022148

Christiano, L., Eichenbaum, M. \& Rebelo, S. (2011). When Is the Government Spending Multiplier Large? Journal of Political Economy, 119(1), 78-121.

https://doi.org/10.1086/659312
Christiano, L. J., Eichenbaum, M. \& Evans, C. L. (2005). Nominal Rigidities and the Dynamic Effects of a Shock to Monetary Policy. Journal of Political Economy, 119(1), 1-45.

https://doi.org/10.1086/426038

Clinton, K., Kumhof, M., Laxton, D. \& Mursula, S. (2011). Deficit reduction: Short-term pain for long-term gain. European Economic Review, 55(1), $118-139$. https://doi.org/10.1016/j.euroecorev.2010.11.006

Coenen, G., Erceg, C. J., Freedman, C., Furceri, D., Kumhof, M., Lalonde, R. \& in't Veld, J. (2012). Effects of Fiscal Stimulus in Structural Models. American Economic Journal: Macroeconomics, 4(1), 22-68.

https://doi.org/10.1257/mac.4.1.22

Coenen, G., McAdam, P. \& Straub, R. (2008). Tax reform and labour-market performance in the euro area: A simulation-based analysis using the New Area-Wide Model. Journal of Economic Dynamics and Control, 32(8), 2543-2583.

https://doi.org/10.1016/j.jedc.2007.09.007

Coenen, G., Mohr, M. \& Straub, R. (2008). Fiscal consolidation in the euro area: Long-run benefits and short-run costs. Economic Modelling, 25(5), 912-932.

https://doi.org/10.1016/j.econmod.2007.11.011

Corsetti, G., Meier, A. \& Müller, G. (2010). Cross-border spillovers from fiscal stimulus. International Journal of Central Banking, 60 (March) :05-37.

Cwik, T. \& Wieland, V. (2011). Keynesian government spending multipliers and spillovers in the euro area. Economic Policy, 26(67), 493-549.

https://doi.org/10.1111/j.1468-0327.2011.00268.x

D'Auria, F., Pagano, A., Ratto, M. \& Varga, J. (2009) A comparison of structural reform scenarios across the EU member states-Simulation-based analysis using the QUEST model with endogenous growth. European Commission Economic Papers $\mathrm{N}^{\circ} 3920$.

http://ec.europa.eu/economy_finance/publications/ pages/publication16461_en.pdf

Eggertsson, G., Ferrero, A. \& Raffo, A. (2014). Can structural reforms help Europe? Journal of Monetary Economics, 61, 2-22.

https://doi.org/10.1016/j.jmoneco.2013.11.006 
Erceg, C. J. \& Lindé, J. (2013). Fiscal consolidation in a currency union: Spending cuts vs. tax hikes. Journal of Economic Dynamics and Control, 37(2), $422-445$.

https://doi.org/10.1016/j.jedc.2012.09.012

Farhi, E. \& Werning, I. (2016). Chapter 31 - Fiscal Multipliers: Liquidity Traps and Currency Unions. In Handbook of Macroeconomics (Vol. 2, pp. 2417-2492).

https://doi.org/10.1016/bs.hesmac.2016.06.006

Forni, L., Gerali, A. \& Pisani, M. (2010). Macroeconomic Effects of Greater Competition in the Service Sector: the Case of Italy. Macroeconomic Dynamics, 14(5), 677-708.

https://doi.org/10.1017/S1365100509990800

Furceri, D. \& Mourougane, A. (2010). The Effects of Fiscal Policy on Output : A DSGE Analysis. OECD Economics Department Working Papers $\mathrm{N}^{\circ} 770$.

https://doi.org/10.1787/5kmfp4z3njg0-en

Galí, J. (2015). Monetary policy, inflation, and the business cycle : an introduction to the new Keynesian framework and its applications. Princeton: Princeton University Press.

Retrieved from http://press.princeton.edu/titles/ 10495.html

Galí, J., López-Salido, J. D. \& Vallés, J. (2007). Understanding the Effects of Government Spending on Consumption. Journal of the European Economic Association, 5(1), 227-270.

https://doi.org/10.1162/JEEA.2007.5.1.227

Guerrieri, L. \& Iacoviello, M. (2015). OccBin: A toolkit for solving dynamic models with occasionally binding constraints easily. Journal of Monetary Economics, 70, 22-38.

https://doi.org/10.1016/j.jmoneco.2014.08.005

in't Veld, J. (2013). Fiscal consolidations and spillovers in the Euro area periphery and core. European Commission Economic Papers $\mathrm{N}^{\circ} 5060$.

http:/ec.europa.eu/economy_finance/publications/ economic_paper/2013/pdf/ecp506_en.pdf

Kaplan, G., Violante, G. L. \& Weidner, J. (2014). The Wealthy Hand-to-Mouth. Brookings Papers on Economic Activity, 0:0 77-153.

https://www.brookings.edu/bpea-articles/thewealthy-hand-to-mouth/

King, R. G., Plosser, C. I. \& Rebelo, S. T. (2002). Production, Growth and Business Cycles: Technical Appendix. Computational Economics, 20(1/2), 87-116. https://doi.org/10.1023/A:1020529028761
Klein, C. \& Simon, O. (2010). Le modèle MÉSANGE réestimé en base 2000. Tome 1-Version avec volumes à prix constants. Insee-Dese, Document de Travail $\mathrm{N}^{\circ} \mathrm{G} 2010 / 03$.

https://www.insee.fr/fr/statistiques/1380857

Mendoza, E., Tesar, L. \& Zhang, J. (2014). Saving Europe?: The Unpleasant Arithmetic of Fiscal Austerity in Integrated Economies. Cambridge, MA. https://doi.org/10.3386/w20200

Ratto, M., Roeger, W. \& in't Veld, J.. (2009). QUEST III: An estimated open-economy DSGE model of the euro area with fiscal and monetary policy. Economic Modelling, 26(1), 222-233. https:// doi.org/10.1016/j.econmod.2008.06.014

Roeger, W. \& in't Veld, J. (2010). Fiscal stimulus and exit strategies in the EU: a model-based analysis. European Commission Economic Papers, 4260:0 1-36. http://ec.europa.eu/economy_finance/publications/ economic_paper/2010/pdf/ecp426_en.pdf

Roeger, W., in't Veld, J. \& Vogel, L. (2010). Fiscal consolidation in Germany. Intereconomics, 45(6), 364-371.

https://doi.org/10.1007/s10272-010-0357-0

Schmitt-Grohé, S. \& Uribe, M. (2003). Closing small open economy models. Journal of International Economics, 61(1), 163-185.

https://doi.org/10.1016/S0022-1996(02)00056-9

Smets, F. \& Wouters, R. (2002). An estimated Stochastic Dynamic General Equilibrium Model of the Euro area. ECB Working Paper Series $N^{\circ} 10$ (171). https://www.ecb.europa.eu/pub/pdf/scpwps/ ecbwp171.pdf

Smets, F. \& Wouters, R. (2003). An Estimated Dynamic Stochastic General Equilibrium Model of the Euro Area. Journal of the European Economic Association, 1(5), 1123-1175. https://doi.org/10.1162/154247603770383415

Smets, F. \& Wouters, R. (2005). Comparing shocks and frictions in US and euro area business cycles: a Bayesian DSGE Approach. Journal of Applied Econometrics, 20(2), 161-183.

https://doi.org/10.1002/jae.834

Smets, F. \& Wouters, R. (2007). Shocks and Frictions in US Business Cycles: A Bayesian DSGE Approach. American Economic Review, 97(3), 586-606. https://doi.org/10.1257/aer.97.3.586

Taylor, J. B. (1993). Discretion versus policy rules in practice. Carnegie-Rochester Conference Series on Public Policy, 39, 195-214.

https://doi.org/10.1016/0167-2231(93)90009-L 
Trabandt, M. \& Uhlig, H. (2011). The Laffer curve revisited. Journal of Monetary Economics, 58(4), 305-327.

https://doi.org/10.1016/j.jmoneco.2011.07.003
Vogel, L. (2012). Structural reforms, fiscal consolidation and external rebalancing in monetary union: A model-based analysis. Economic Modelling, 29(4), 1286-1298.

https://doi.org/10.1016/j.econmod.2012.04.018 


\section{CALIBRATION}

In the linearized form of the model, we identify three sets of parameters: (i) structural parameters, (ii) policy parameters and (iii) reduced-form parameters. First, structural parameters are parameters (technology, preferences, etc.) deemed purely exogenous, accounting for mechanisms outside of the model and not susceptible to change across simulations. Second, policy parameters correspond to discretely chosen parameters by fiscal and monetary authorities such as the inflation target and the tax rates. Lastly, some reduced-form coefficients of the model cannot be calibrated freely and are combinations of actual steady state values of the endogenous variables determined by the steady state equations. These coefficients are solved for a given set of structural and policy parameters.

Most structural parameters are calibrated based on the DSGE literature, and in order to set policy parameters to their observed values.

First, a few structural parameters are calibrated on National Accounting data. That is the case for the headcount of the total employed population $\mathbb{N}$, the respective regional share of this population $n$, the quarterly GDP per capita growth rate $g$, the HICP quarterly inflation $\Pi$, and $\alpha^{i}$ the degree of trade openness. For the latter, intra-area trade flows are explicitly taken into account using bilateral trade data from the CHELEM database. In addition, the technology parameter $\alpha$ is computed as the GDP-weighted average of gross operating surplus to value added ratios, computed at market prices.

However, most structural parameters have no direct real world counterparts. Hence, we proceed to an extensive literature review based on Annicchiarico et al. (2013), Auray et al. (2011), Bayoumi et al. (2004), Cacciatore et al. (2012), Clinton et al. (2011), Coenen et al. (2008), Eggertsson et al. (2014), Erceg and Lindé (2013), Forni et al. (2010), Kaplan et al. (2014), Ratto et al. (2009), Smets and Wouters (2002), Smets and Wouters (2003, 2005), Trabandt and Uhlig (2011), Vogel (2012). Using this review, we then select a value for each parameter that is close to the median of those observed in the literature, which have been estimated using a range of different methods, such as Bayesian methods on macro data or directly on micro data. However, except for the depreciation rate and the elasticity of substitution between goods, we do not have sufficient information to be able to calibrate each structural parameter to a region-specific value. Therefore, we assume that both our region share the same parameter value often based on euro area values. Regarding the other mentioned parameters, the depreciation rate, and the elasticity of substitution between goods, linked to the markup on goods, are calibrated using region-specific data found in D'Auria et al. (2009). A detailed discussion on the differences observed across models/papers for crucial parameters is given in Campagne and Poissonnier (2016a).

However, for an arbitrary calibration of structural parameters, the steady state structure of the model lead to values of the endogenous variables that differ from observed data, for instance the production level. Yet, our model also needs to be able to match some of the main economic indicators as measured in the National Accounts.

As such, having identified a list of structural and policy parameters, targets for some steady state values of endogenous variables are also identified in the National Accounts. In particular, six targets are selected: (i) the nominal main refinancing interest rate, (ii) the share of public consumption in GDP, (iii) the level of GDP, (iv) the number of hours worked, (v) the terms of trade, and (vi) the ratio of nominal GDP between regions. As explained in more details in Campagne and Poissonnier (2016a), the resolution of steady state equations allows to set the value for some structural parameters by reverse inference.

Those six National Accounting targets are calibrated as follows. The nominal main refinancing interest rate target is computed on the 3-months Euribor rate. The share of public consumption in GDP is directly computed using the Eurostat National Accounts at current prices, so as for the level of GDP, and the ratio of GDP between the two regions. The terms of trade are computed as the ratio of Purchasing Power Parities of GDP normalizing the North region to unity. Weights for the aggregation across regions are therefore logically based on regional GDPs. Lastly, the number of hours worked in each region is computed using the Labor Force Survey data. This survey allows to estimate employment in capita terms, the average number of actual weekly hours worked in the main job, the average number of actual weekly hours worked in the second job, and the number of employed persons having a second job. This allows to reconstruct a homogeneous number of hours worked in each region, based on the small approximation that no worker holds more than two jobs. 
BASELINE SCENARIO AND ROBUSTNESS CHECKS

Table A2-1

Measures of fit according various calibrations

\begin{tabular}{|c|c|c|c|c|c|c|}
\hline & \multirow{2}{*}{$\begin{array}{c}\text { Central } \\
\text { calibration }\end{array}$} & \multicolumn{5}{|c|}{ Alternative calibrations } \\
\hline & & 2 & 3 & 4 & 5 & 6 \\
\hline \multicolumn{7}{|c|}{ Correlation of simulated series and observed data } \\
\hline Consumption growth (North) & 0.74 & 0.32 & 0.39 & 0.34 & 0.47 & 0.67 \\
\hline Consumption growth (South) & 0.93 & 0.46 & 0.54 & 0.50 & 0.54 & 0.94 \\
\hline Investment growth (North) & 0.99 & 0.92 & 0.88 & 0.87 & 0.97 & 0.99 \\
\hline Investment growth (South) & 0.99 & 0.95 & 0.96 & 0.97 & 0.98 & 0.99 \\
\hline Output growth (North) & 0.98 & 0.85 & 0.82 & 0.67 & 0.81 & 0.98 \\
\hline Output growth (South) & 0.97 & 0.88 & 0.89 & 0.89 & 0.91 & 0.97 \\
\hline Public debt growth (North) & 0.99 & 0.96 & 0.95 & 0.91 & 0.97 & 0.99 \\
\hline Public debt growth (South) & 0.97 & 0.89 & 0.90 & 0.89 & 0.91 & 0.98 \\
\hline Inflation (North) & 0.46 & 0.68 & 0.57 & 0.46 & 0.57 & 0.48 \\
\hline Inflation (South) & 0.61 & 0.20 & 0.33 & 0.27 & 0.49 & 0.63 \\
\hline Interest rate variation & 1.00 & 0.97 & 1.00 & 1.00 & 1.00 & 1.00 \\
\hline Interest rate level & 1.00 & 0.94 & 0.98 & 0.99 & 0.97 & 0.99 \\
\hline \multicolumn{7}{|c|}{ Cross-correlation of output and growth } \\
\hline Data (North) & 0.64 & 0.64 & 0.64 & 0.64 & 0.64 & 0.64 \\
\hline Simulated series (North) & 0.36 & 0.18 & -0.13 & -0.40 & 0.14 & 0.44 \\
\hline Data (South) & 0.35 & 0.35 & 0.35 & 0.35 & 0.35 & 0.35 \\
\hline Simulated series (South) & 0.41 & 0.38 & 0.36 & 0.39 & 0.34 & 0.22 \\
\hline \multicolumn{7}{|c|}{ Ratio of simulated over observed volatility } \\
\hline Consumption growth (North) & 1.31 & 1.87 & 1.39 & 1.83 & 1.43 & 1.36 \\
\hline Consumption growth (South) & 1.03 & 0.96 & 0.83 & 0.78 & 0.62 & 0.96 \\
\hline Investment growth (North) & 1.03 & 1.18 & 1.08 & 1.10 & 1.06 & 1.01 \\
\hline Investment growth (South) & 1.08 & 1.09 & 0.88 & 0.88 & 0.93 & 1.11 \\
\hline Output growth (North) & 1.01 & 1.31 & 1.14 & 1.05 & 0.71 & 0.98 \\
\hline Output growth (South) & 1.00 & 1.06 & 1.05 & 1.00 & 0.94 & 1.05 \\
\hline Public debt growth (North) & 1.01 & 1.13 & 1.08 & 1.06 & 0.93 & 1.00 \\
\hline Public debt growth (South) & 1.15 & 1.18 & 1.05 & 1.05 & 1.01 & 1.14 \\
\hline Inflation (North) & 0.70 & 0.52 & 0.64 & 0.56 & 0.46 & 0.74 \\
\hline Inflation (South) & 0.55 & 0.72 & 0.77 & 0.84 & 0.59 & 0.56 \\
\hline
\end{tabular}

Note: Each column indicates the correlation between observed quarterly data over the period 2004-2015and their simulated counterparts using different calibration of deep parameters.

Central calibration corresponds to parameter values in Table 2, calibration 2 to a low share $(\mu=0.15)$ of Non Ricardian Households in both regions, calibration 3 to a high share $(\mu=0.50)$ of Non Ricardian Households in both regions, calibration 4 to a low (respectively high) share of Non Ricardian Households in the North (respectively in the South), calibration 5 introduces asymmetry in goods elasticity of substitution $\left(\theta^{\mathrm{N}}=3\right.$, $\left.\theta^{S}=10\right)$, whereas calibration 6 considers asymmetry in labour elasticity of substitution $\left(\theta_{w}^{N}=2.5, \theta_{w}^{S}=6.5\right)$.

Source: Authors' computations. Simulations with the Meleze model. 
Table A2-2

Estimated standard deviation and persistence for structural shocks

\begin{tabular}{|c|c|c|c|c|}
\hline \multirow[b]{2}{*}{ Shock } & \multicolumn{2}{|c|}{ Standard deviation } & \multicolumn{2}{|c|}{ Persistence } \\
\hline & North & South & North & South \\
\hline Monetary policy & 0.012 & & 0.149 & \\
\hline Productivity & 0.028 & 0.027 & 0.827 & 0.532 \\
\hline Preference & 0.017 & 0.018 & 0.087 & 0.100 \\
\hline Investment cost & 0.027 & 0.033 & 0.588 & 0.790 \\
\hline Public spending & 0.020 & 0.026 & 0.890 & 0.991 \\
\hline Transfers & 0.029 & 0.034 & 0.508 & 0.888 \\
\hline Net foreign assets & 0.026 & 0.030 & 0.000 & 0.000 \\
\hline Labour supply & 0.046 & 0.072 & 0.994 & 0.994 \\
\hline Financial spreads & 0.016 & 0.017 & 0.000 & 0.000 \\
\hline Public assets measurement error & 0.018 & 0.019 & 0.000 & 0.000 \\
\hline Inflation measurement error & 0.012 & 0.012 & 0.000 & 0.000 \\
\hline
\end{tabular}

Note: Bayesian estimation of shocks persistence and standard deviation over 2004-2015. Measurement errors are allowed in the inflation and public assets equation in the Bayesian estimation process.

Source: Authors' computations. Simulations with the Meleze model.

Figure A2-I

Underlying standardized structural shocks from 2004 to 2015

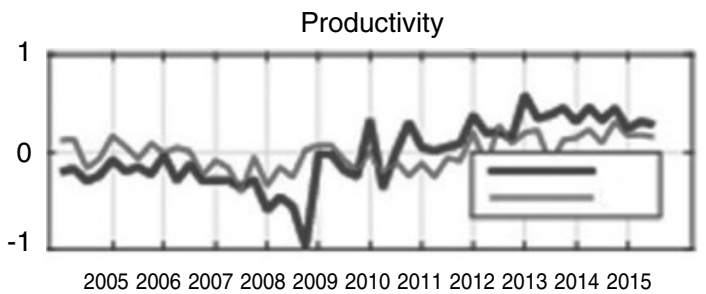

Investment Cost

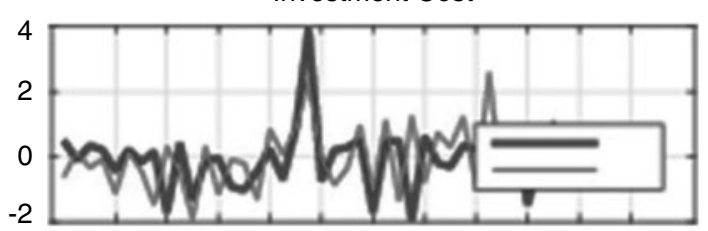

20052006200720082009201020112012201320142015

Public Transfers

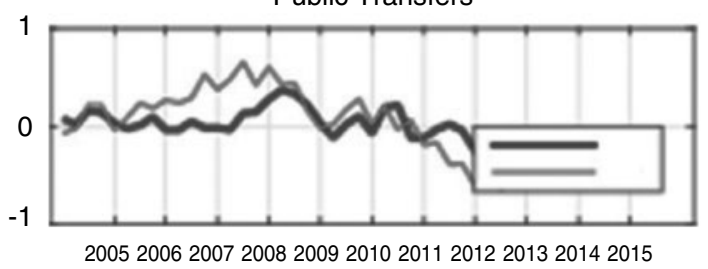

Labor Supply

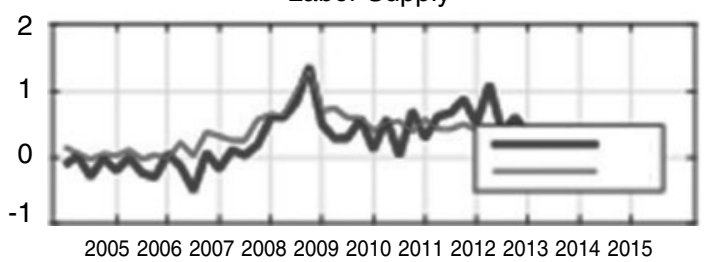

Preference

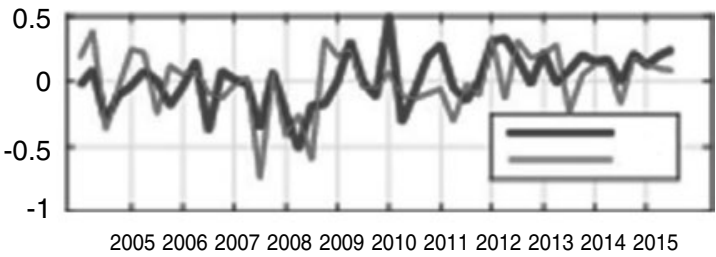

Public Spending

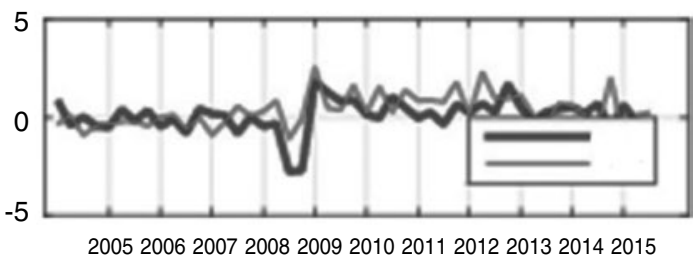

External Assets

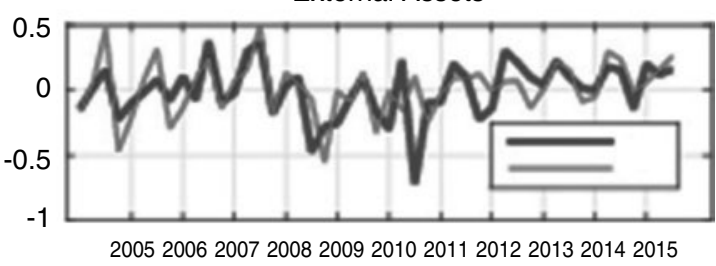

Monetary Policy

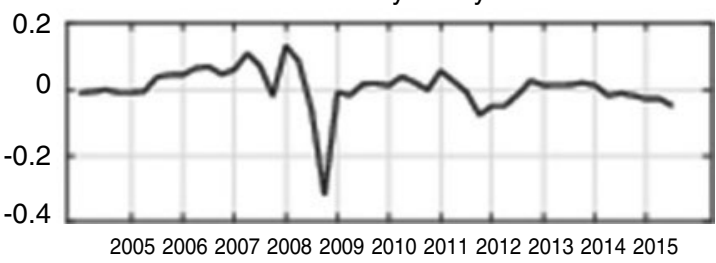

Note: North represents Belgium, Germany, France and the Netherlands, whereas South includes Greece, Ireland, Italy, Spain and Portugal. Shocks are displayed in percent of estimated standard deviation.

Source: Authors' computations. Simulations with the Meleze model. 


\section{ADDITIONAL FIGURES}

Figure A3-I

Spillovers of spending-based consolidation
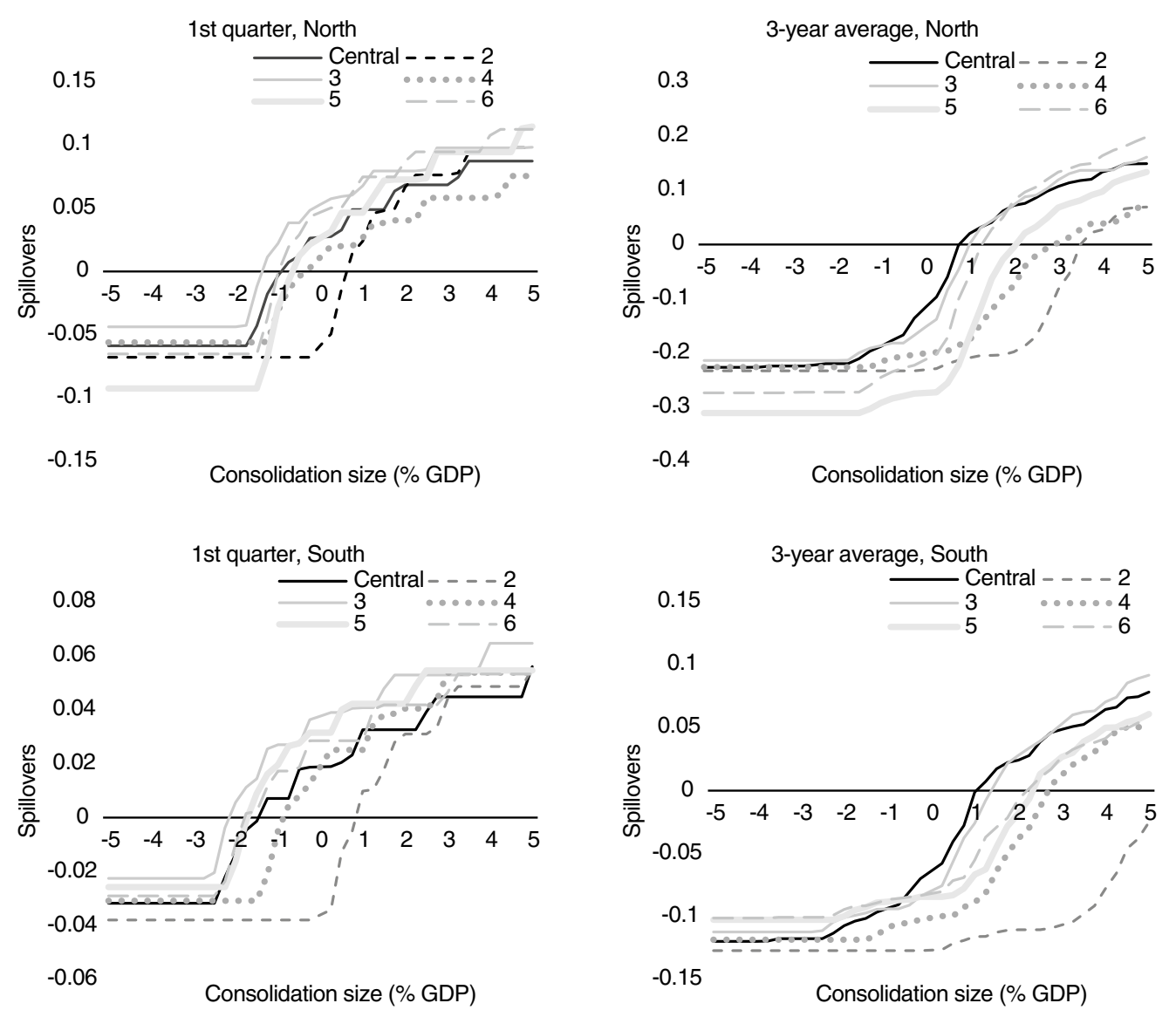

Note: The x-axis corresponds to the ex-ante spending-based deficit reduction in \% of GDP in the North region for top panels and in the South region for bottom panels. Spillovers (y-axis) are computed as the marginal foreign effect of fiscal shocks divided by their marginal domestic effect (that is where the shock occurs). "1st quarter" corresponds to the impact multiplier, whereas "3-year average" corresponds to a multiplier computed over three years.

Central calibration corresponds to parameter values in Table 2, calibration 2 to a low share $(\mu=0.15)$ of Non Ricardian Households in both regions, calibration 3 to a high share $(\mu=0.50)$ of Non Ricardian Households in both regions, calibration 4 to a low (respectively high) share of Non Ricardian Households in the North (respectively in the South), calibration 5 introduces asymmetry in goods elasticity of substitution $\left(\theta^{N}=3\right.$, $\left.\theta^{S}=10\right)$, whereas calibration 6 considers asymmetry in labour elasticity of substitution $\left(\theta^{N}=2.5, \theta^{S}=6.5\right)$.

Reading Note: for an ex-ante spending-based consolidation of $2 \%$ of GDP in the North (top panels), the spillover of 0.05 to 0.1 means that the fiscal shock in the North has an effect in the South reaching from $5 \%$ to $10 \%$ the size it has in the North during the first quarter (left figures). Source: Authors' computations. Simulations with the Meleze model. 


\section{Spillovers of VAT-based consolidation}
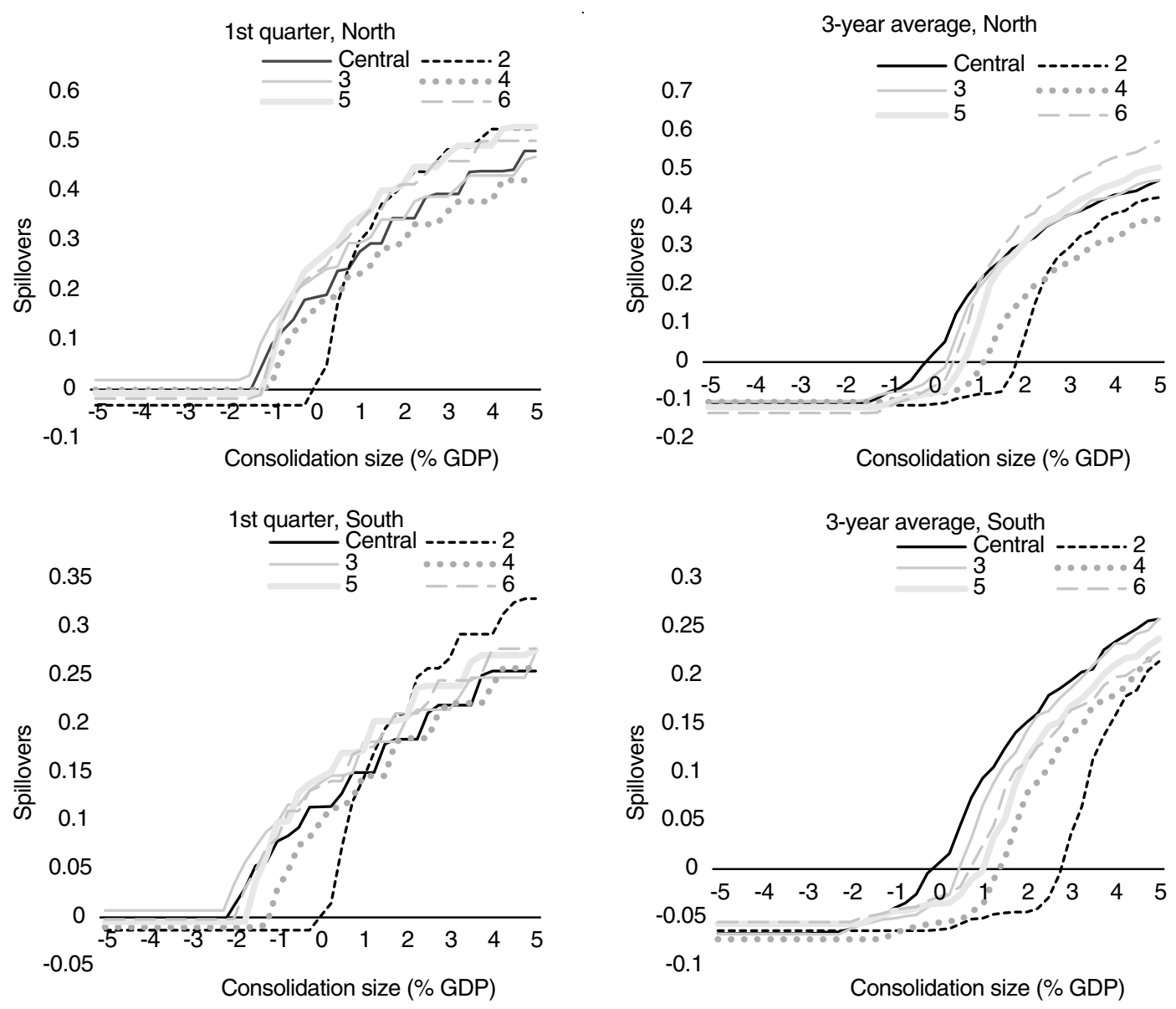

Note: The x-axis corresponds to the ex-ante VAT-based deficit reduction in $\%$ of GDP in the North region for top panels and in the South region for bottom panels. Spillovers (y-axis) are computed as the marginal foreign effect of fiscal shocks divided by their marginal domestic effect (that is where the shock occurs). "1st quarter" corresponds to the impact multiplier, whereas "3-year average" corresponds to a multiplier computed over three years.

Central calibration corresponds to parameter values in Table 2, calibration 2 to a low share $(\mu=0.15)$ of Non Ricardian Households in both regions, calibration 3 to a high share $(\mu=0.50)$ of Non Ricardian Households in both regions, calibration 4 to a low (respectively high) share of Non Ricardian Households in the North (respectively in the South), calibration 5 introduces asymmetry in goods elasticity of substitution $\left(\theta^{N}=3\right.$, $\left.\theta^{S}=10\right)$, whereas calibration 6 considers asymmetry in labour elasticity of substitution $\left(\theta_{w}^{N}=2.5, \theta^{S}=6.5\right)$.

Reading Note: for an ex ante VAT-based consolidation of $2 \%$ of GDP in the North (top panels), the spillover of 0.3 to 0.4 means that the fiscal shock in the North has an effect in the South reaching from $30 \%$ to $40 \%$ the size it has in the North during the first quarter (left figures).

Source: Authors' computations. Simulations with the Meleze model. 